\title{
THE BADEN CULTURE FINDS FROM GOSZCZA SITE 1 (KIELNIK): NEW ARCHAEOLOGICAL, ANTHROPOLOGICAL, ARCHAEOZOOLOGICAL AND ARCHAEOBOTANICAL DATA
}

\author{
Maciej NowaK ${ }^{1}$, JarosŁaw Wilczyński ${ }^{2}$, JarosŁaw Wróbel ${ }^{3}$, Magda Kapcia $^{4}$, \\ Magdalena Moskal-Del Hoyo ${ }^{4}$
}

A u th o r s' a d d r e s s e s: 1 - Pracownia Archeologiczna Maciej Nowak, e-mail (corresponding author): archeomaciek@gmail.com, ORCID: 0000-0003-4960-6049; 2 - Institute of Systematics and Evolution of Animals, Polish Academy of Sciences, Sławkowska 17, 31-016 Kraków, Poland, ORCID: 0000-00029786-0693; 3 - Department of Anthropology of Institute of Zoology, Jagiellonian University, Gronostajowa 9, 30-387 Kraków, Poland, ORCID: 0000-0002-3481-899X; 4 - W. Szafer Institute of Botany, Polish Academy of Sciences, Lubicz 46, 31-512 Kraków, Poland; M. Kapcia, e-mail: m.kapcia@botany.pl, ORCID: 00000001-7117-6108; M. Moskal-del Hoyo, e-mail: m.moskal@botany.pl, ORCID: 0000-0003-3632-7227

A b s t r a c t. In spring 2019, rescue excavations were conducted at Goszcza 1 (Kielnik) site in connection with construction of a dwelling house. As a result, eleven archaeological features of various chronology were identified. The most abundant materials, dating to the Late Classic period of the Baden culture in Lesser Poland (the end of the $4^{\text {th }}$ millennium and the beginning of the $3^{\text {th }}$ millennium $\mathrm{BC}$ ), were found in four pits. At the bottom of two features (nos 4 and 6) human skeletons were discovered. In the present study, only materials discovered in features attributed to the Baden culture are discussed, including pottery finds, flint artefacts, and fragments of human and animal bones. Macroscopic plant remains coming from three archaeological features have also been investigated.

K e y w o r d s: Neolithic, Baden culture, funerary rites, anthropology, archaeozoology, archaeobotany

\section{INTRODUCTION}

Site 1 in Goszcza (Kielnik, Comm. Kocmyrzów-Luborzyca) is located about 20 kilometres north of Kraków in the area of the Miechów Upland (KONDRACKI 2002: 264, 265) in the drainage of the Pokojówka, a left-bank tributary of the Szreniawa River (Fig. 1). The site is situated on the ridge and southern slopes of a latitudinally stretched loess hill. The site was identified in 1987 by surveys carried out within the framework of the Polish Archaeological Record programme (site number: 100-57/83), which revealed numerous artefacts dated to the Neolithic (the Lengyel and Baden cultures) and to the Bronze Age (the Trzciniec culture). In addition, human bone remains were found on the surface (KRUK 1987). In the $21^{\text {st }}$ century, small-scale excavations

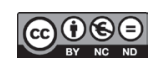

Publikacja jest udostępniona na licencji Creative Commons (CC BY-NC-ND 3.0 PL) 

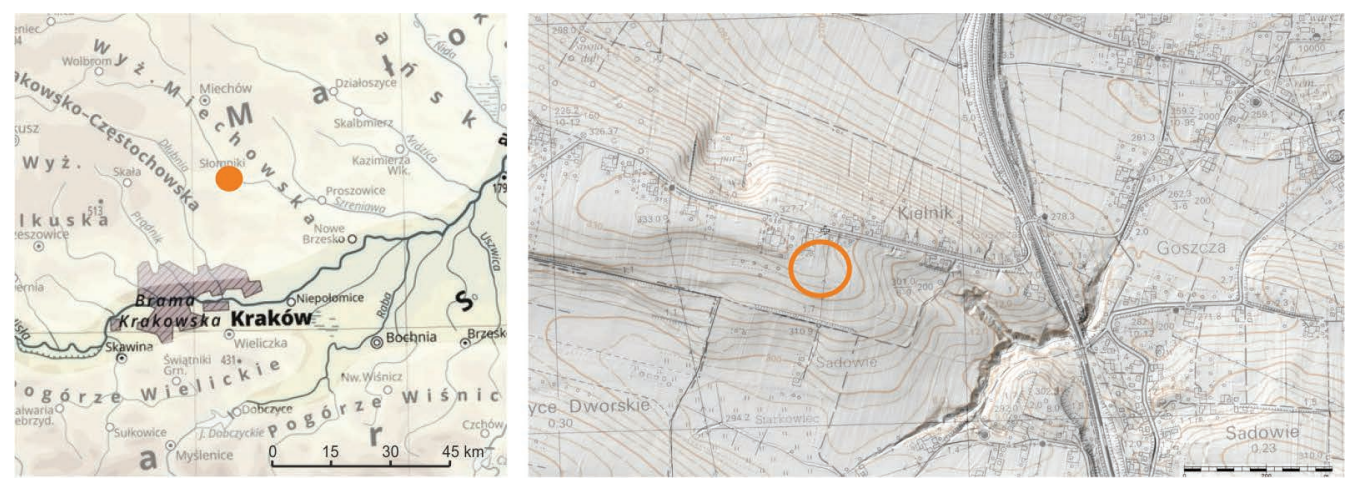

Fig. 1. Location of site 1 in Goszcza. Drawn by K. Nawrot

were carried out in the site prior to the construction of family housing. As a result of this research, several isolated Neolithic features were identified, along with a grave of a soldier dated to the First World War (Czarnowicz, Ochat-Czarnowicz 2011). At present, the site is under investigation in connection with archaeological research preceding the construction of the S7 expressway (personal information from P. Micyk).

In spring 2019, the rescue excavation linked with dwelling house construction was conducted at the site. The research area was situated at the top of a small elevation in the north-eastern part of the site (Fig. 1). Within an area of 0.78 are, nine archaeological features were identified (Fig. 2). The chronology and cultural affiliation could

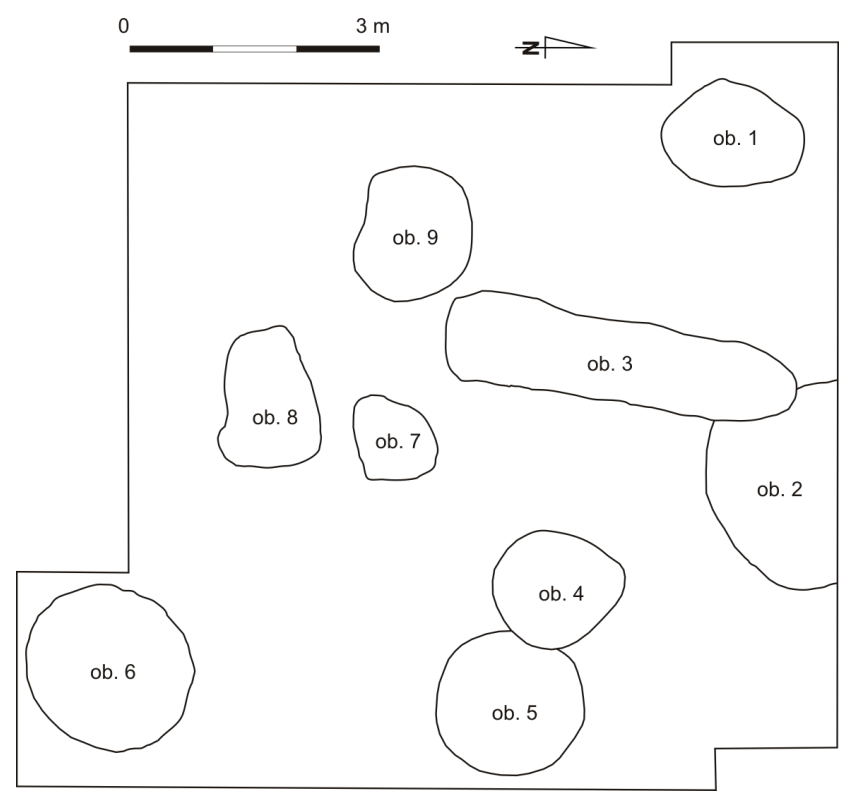

Fig. 2. Goszcza site 1. Location of the discovered features in the research area. Features nos 2, 5 and 6 belong to the Baden culture. Feature no. 4 contains a human skeleton possibly linked to this culture. 
be determined for five of them. Feature no. 3 has been dated to the Early Medieval Period and feature no. 1 has been linked with the Lusatian culture (Bronze Age Period $\mathrm{V}$ or the Hallstatt period). The most abundant materials link with the Late Classic Period of the Baden culture in Lesser Poland (pits nos 2, 5 and 6). At the bottoms of features nos 4 and 6 , human skeletons were discovered.

The study presents the analysis of the materials found within archaeological features of the Baden culture, such as pottery finds, flint artefacts, human and animal bones, as well as plant macro-remains.

\section{CHARACTERISTICS OF FEATURES LINKED WITH THE BADEN CULTURE}

Ceiling parts of features were identified after mechanical removal of a $40 \mathrm{~cm}$ deep topsoil layer. Despite numerous traces of animal activity, the features were well discernible against the background of a yellow layer of undisturbed soil.

Feature no. 2 was identified by the northern boundary of the trench (Fig. 3: a, b). Its range exceeded the primarily designated area of the research. Despite widening the area of excavation, the full exploration of this feature proved impossible. At the level of discovery, feature no. 2 resembled an oval having a maximum diameter of 2.2 meters. Its northern part was disturbed by an Early Medieval trench (feature no. 3). The pit was $80 \mathrm{~cm}$ deep, and in cross-section it had the shape of a trapeze with a flat bottom and a clearly discernible trough-shaped, black ceiling part, $50 \mathrm{~cm}$ thick and with irregular borders. It was highly saturated with artefacts. The lower border of this layer was indicated by a horizon of calciferous precipitations and lumps of daub. At the sides, lumps of loess which had collapsed from the walls, mixed with brownish soil, were noticeable in the cross-section. At the bottom of the pit, a thin layer was recorded, probably connected with the time when the pit remained in use. Within this layer, a complete amphora (Fig. 3: c; Fig. 10: a) and a flint axe (Fig. 12: e) arranged one next to another were found by the eastern border of the pit (Fig. 3: c, d). It is worth noting the presence of a human bone registered in the topsoil over the feature.

At the level of its discovery, feature no. 6 (Fig. 4: a, c) was circular with a diameter of 2.1 meters. It was trapezium-shaped in profile $(30 \mathrm{~cm}$ deep) with an outstanding, centrally located, loose, black-grey layer of a trough-like shape. Its borders were hardly noticeable. At both sides, a loose, black-brownish layer was visible, in which a human skeleton was found. It was located in the north-eastern part of the pit, placed on the back with the skull lying on the right side, the left arm maximally bent with the palm in the shoulder blade region and the right arm straight. The spine was bent to the right - in the collarbone region it was unnaturally bent at a different angle; left leg straight; bones of the right leg disordered. At both sides of the skull and of the upper part of the torso, there were several stones arranged - one of them (at the southern side) was a fragment of a quern stone. Some disturbances in the anatomical order (in 
Feat. no. 2
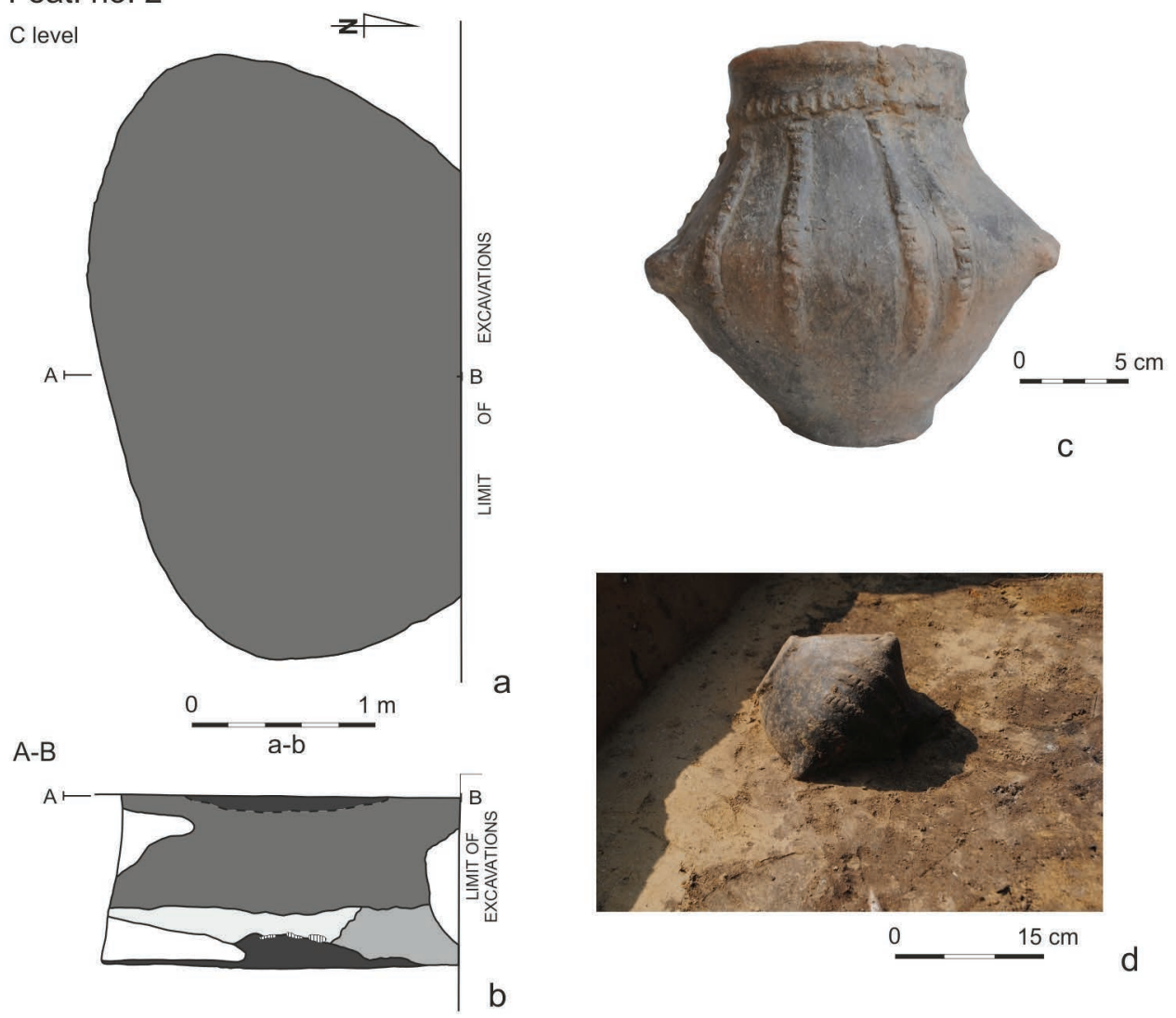

Fig. 3. Goszcza site 1. Plan and cross-section of feature no. $2(a, b)$, the amphora found at the bottom of this feature (c ) and its in situ location (d). Drawn by K. Nawrot

the region of the spine and the right femur) indicate that the skeleton was disturbed post mortem (by a trench?) or it had already been partially decomposed when buried (a secondary burial or a burial without filling the grave pit back) (Fig. 4: b; Fig. 5).

Another feature, pit no. 5 (Fig. 4: f), has a circular outline and a diameter of 1.7 meters. Its cross-section is 1 meter deep, in the shape of trapezium with a flat bottom. The arrangement of layers is typical for pits of that type. The ceiling part contains a trough-like layer of black soil with noticeable loess collapses at both sides. A coneshaped deposit at the bottom is evident as well. It is worth mentioning one of the deposits below the layer of collapsed loess. It is a $30 \mathrm{~cm}$-deep layer - black, compact, and containing numerous potsherds. Feature no. 5 is directly adjacent to feature no. 4 .

The skeleton discovered at the bottom of feature no. 4 may hypothetically be a Baden culture burial which was later disturbed by a younger trench (feature no. 12) dated to the Hallstatt period (Lusatian culture) (Fig. 4: g). This interpretation is based on the layout of layers in the profile and the disturbance of skeleton elements, some of which were registered even $40 \mathrm{~cm}$ above the pit's bottom. The feature at the level 
Feat. no. 6

B level

D level
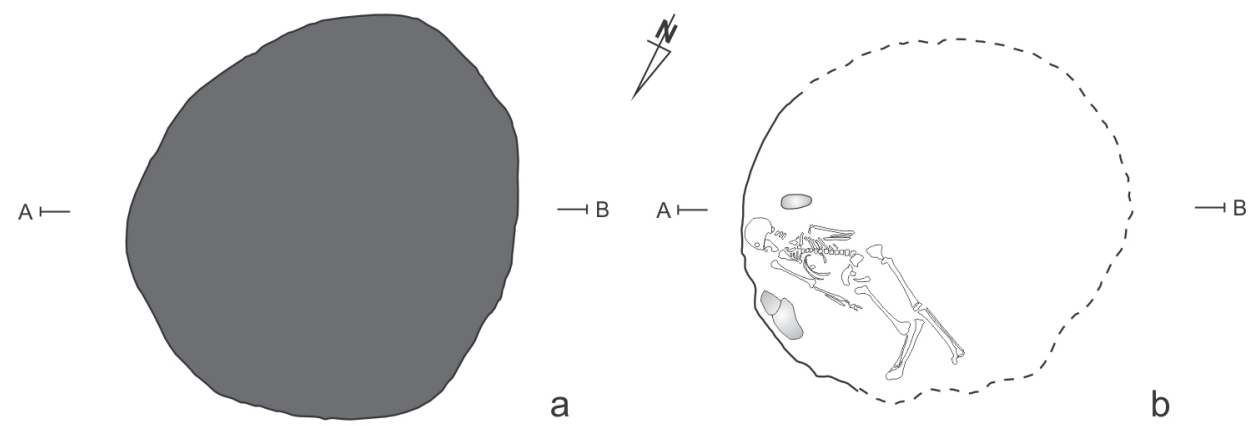

A-B
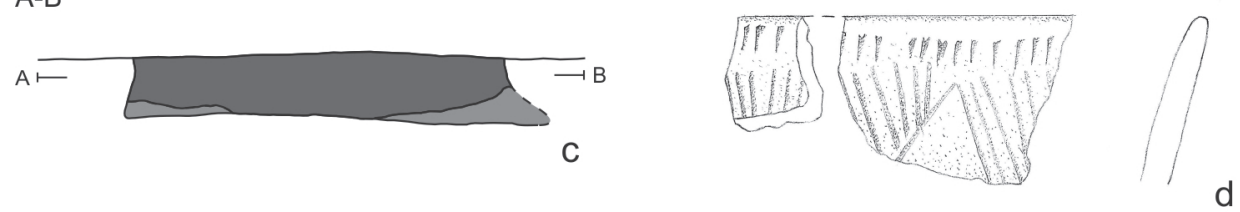

Feat. no. 4,5

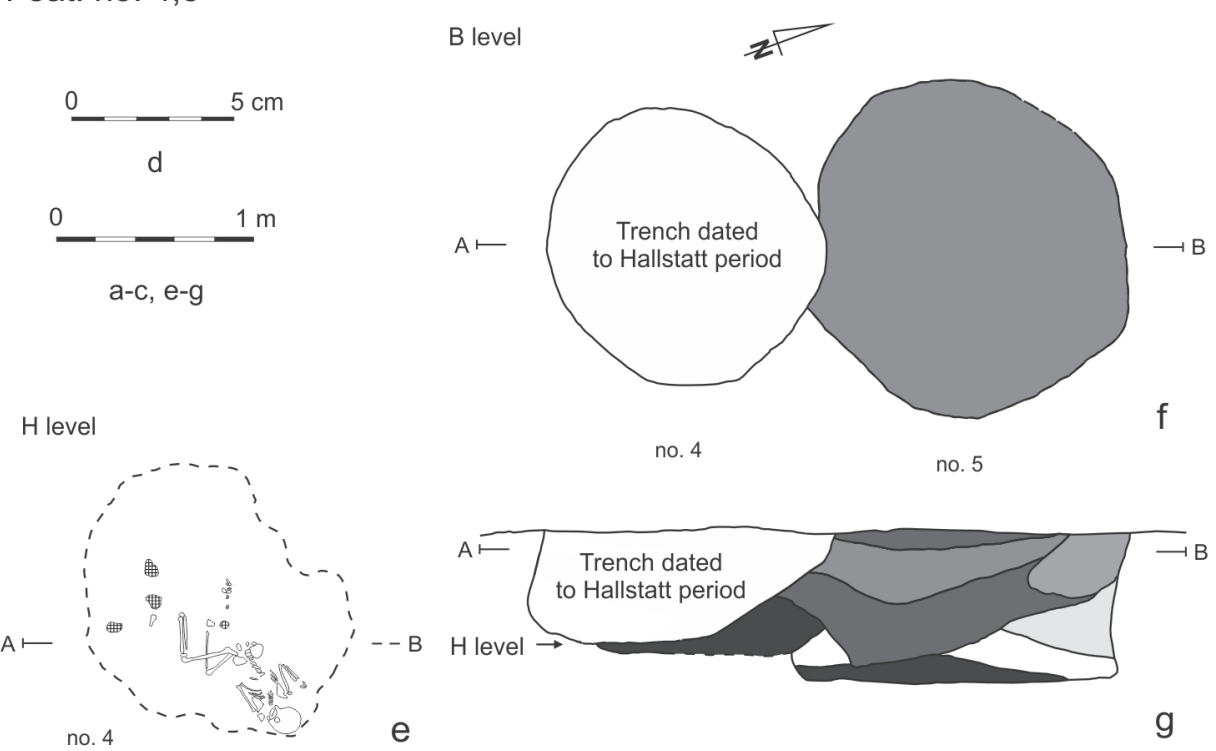

Fig. 4. Goszcza site 1. Plans and cross-sections of features no. 6 (a, c), nos 4, 5 (f, g), and the levels with human remains from features no. 6 (b) and no. 4 (e). Drawn by K. Nawrot. Characteristic pottery fragments from feature no. 6 (d). Drawn by W. Rumian

of discovery was circular with a diameter of 1.5 meters. A tongue-shaped, grey-black discoloration was noticeable in the cross-section. It reached the level of the skeleton in the floor part of the feature (the floor part was dug into a compact, yellow layer of undisturbed soil). The burial was situated at the bottom of the pit (Fig. 4: e). The 


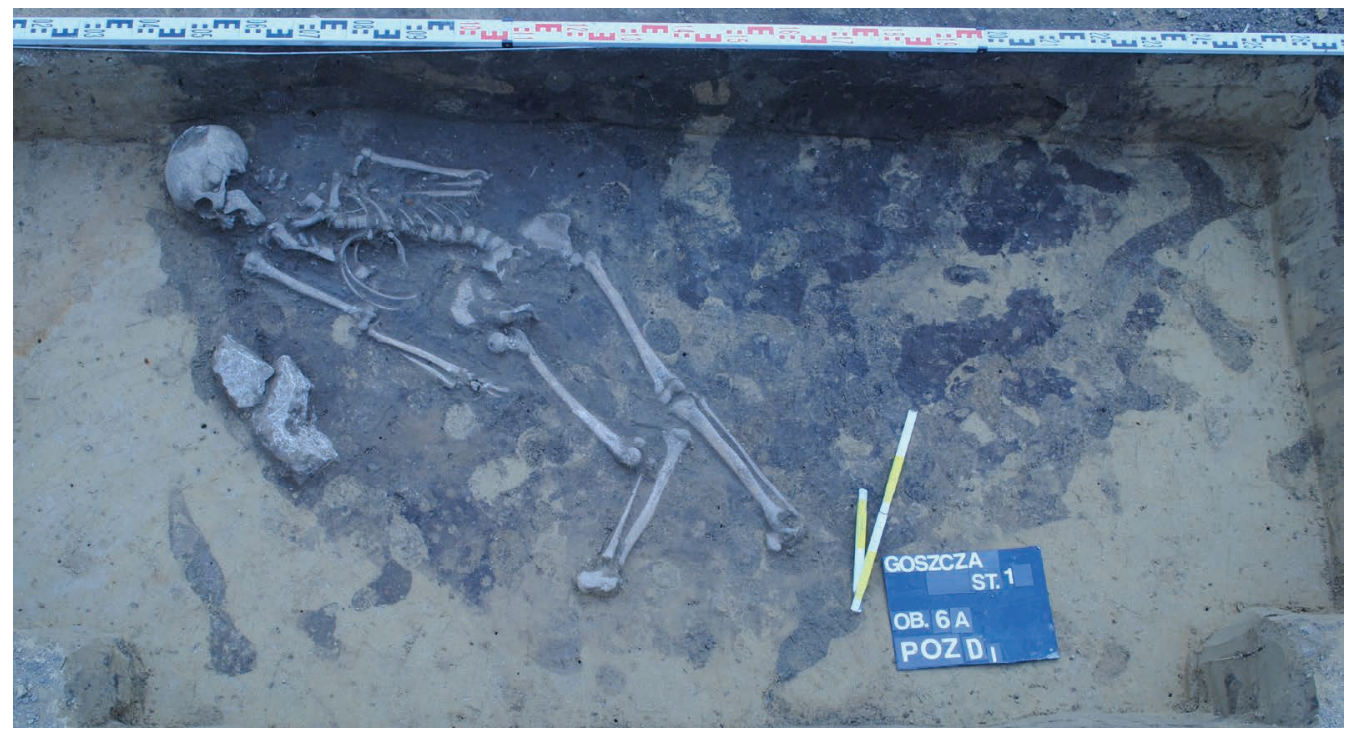

Fig. 5. Goszcza site 1. Photograph from feature no. 6 with the skeleton. Photo by M. Nowak

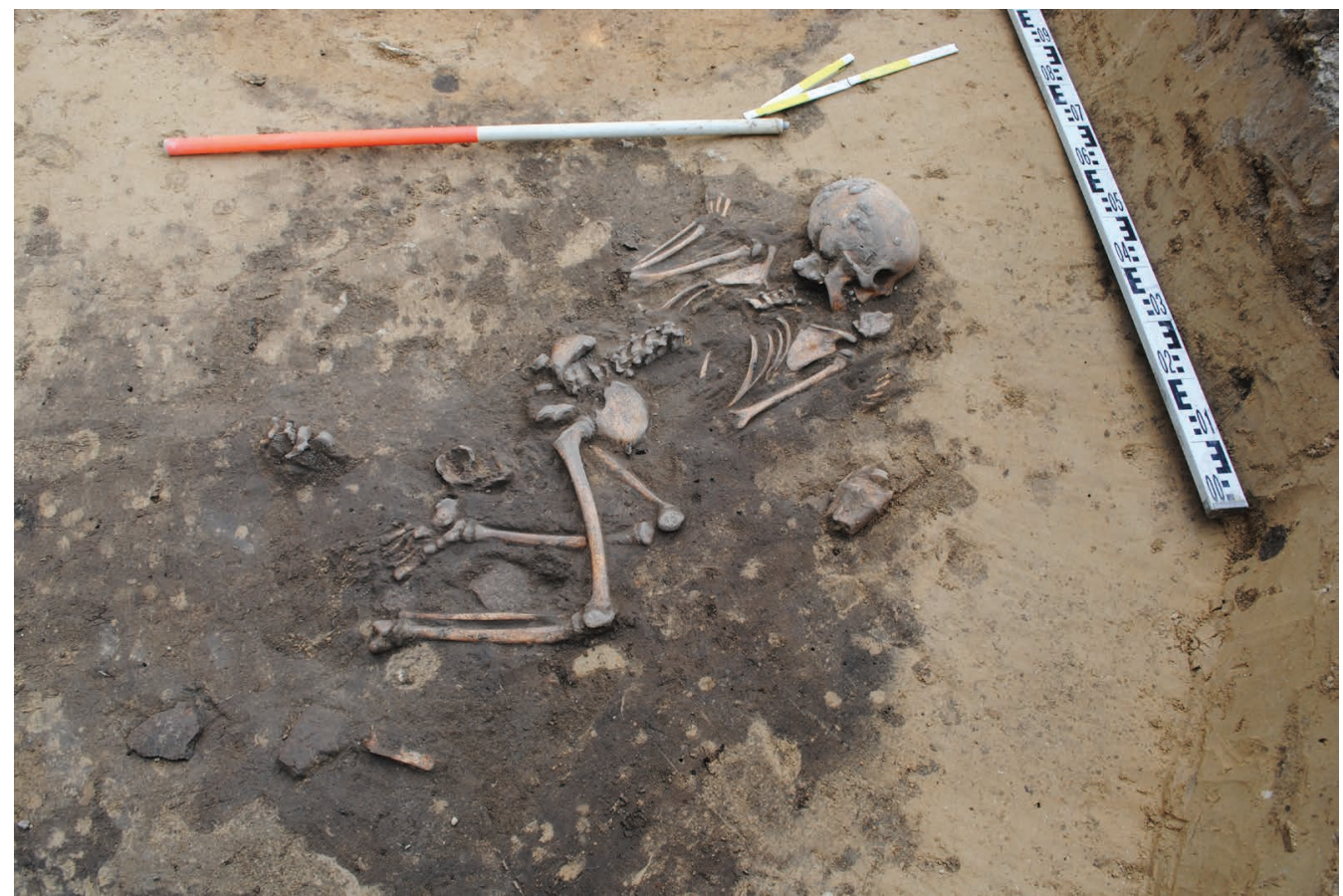

Fig. 6. Goszcza site 1. Photograph from feature no. 4 with the skeleton. Photo by M. Nowak

deceased was placed on the belly, leaning to the left side, with the arms strongly bent at the elbows and the legs pulled up on the left side (Fig 6). Five thoracic vertebrae had been displaced and were found in a compact order behind the feet of the deceased. 


\section{MATERIALS AND METHODS}

\section{Pottery}

Pottery materials were elaborated on the basis of numerous Baden culture finds from the Kraków region - mainly from the area of Nowa Huta - using the terminology worked out for them during earlier analyses (BOBER 1993, 1994, 1995, 1998, 2015; GodŁowsKa 1968, 1979; KozŁowsKi 1968; RooK 1971; SocHACKi 1988). Taking into account the technology of production, two groups of pottery were distinguished. The first group (group A) is characterized by carefully treated and smoothed surfaces. The second group (group B) is comprised of vessels with uneven and/or smeared bottom parts and bodies. The identified forms of vessels are described in connection with their ornamentation. Apart from ceramic vessels, the analysis also includes characteristics of spindle whorls and their fragments.

\section{Lithic materials}

Flint artefacts were divided into groups taking into account raw materials (KACZANOWsKa, Kozlowski 1976; PelisiaK 2006), technological aspects of production, and typological description of tools (GINTER, KOZŁOWSKI 1990; KACZANOWSKA 1982/1983).

\section{Anthropological analysis}

The sex and age of the examined human bones were determined on the basis of standard methods applied in historical anthropology and bioarchaeology (BUIKSTRA, Ubelaker 1994; Acsadi, Nemeskeri 1970; Piontek 1999; Scheuer, Black 2004; CuHna et al. 2009).

\section{Archaeozoological analysis}

The bone remains from Goszcza were identified based on comparative material stored in the collection of the Institute of Systematics and Evolution of Animals in Kraków and publications concerning the anatomy of mammalian species (SCHMID 1972; HiLLSON 2005). Two quantified calculations were made of the remains - NISP (Number of Identified Specimens) and MNI (Minimum Number of Individual Animals) (Klein, Cruz-Uribe 1984; Lyman 1994; Reitz, Wing 1999). Due to significant fragmentation and lack of characteristic features, some of the bone remains were generally assigned to two animal size categories: large (cattle/horse size) and medium mammals (pig/goat/sheep size). Further, bone fragments without discernible morphological features were classified as undetermined. All the bone remains were subjected to detailed observations in order to identify marks left by humans (cut marks, traces of burning) and by animal activity (gnawing marks) (BINFORD 1981; Haynes 1983; Shipman et al. 1984; Lyman 1994; Reitz, Wing 1999; Fosse et al. 2012). The age of animals represented at the Goszcza site, where possible, was 
determined on the basis of the degree of eruption and abrasion of individual teeth (LutNicki 1972; Lasota-MoskalewsKa 2007; Hillson 2005).

\section{Archaeobotanical analysis}

During archaeological excavation four soil samples of a total volume of 33 litres were taken from three features (nos 2, 5, 6; Tab. 1), which were later floated with meshes of 0.5 and $1.0 \mathrm{~mm}$. The samples contained charred and uncharred plant

Table 1. Goszcza site 1. Charred macroscopic plant remains

\begin{tabular}{|c|c|c|c|c|c|}
\hline Feature ID & \multirow{3}{*}{$\begin{array}{l}\text { Type of plant } \\
\text { remains }\end{array}$} & 5 & 5 & 6 & 2 \\
\hline Depth & & $20-40 \mathrm{~cm}$ & $50-60 \mathrm{~cm}$ & $20-40 \mathrm{~cm}$ & $70-80 \mathrm{~cm}$ \\
\hline Sample volume (litres) & & 10.5 & 6 & 8.5 & 8 \\
\hline Cultivated plants & & & & & \\
\hline Triticum dicoccum chaff & chaff & 64 & 5 & & \\
\hline Triticum monococcum chaff & chaff & 8 & & & \\
\hline Triticum dicoccum & grain & 3 & & 11 & \\
\hline Triticum dicoccum/monococcum chaff & chaff & & & & 3 \\
\hline Triticum sp. & chaff & 17 & & & 1 \\
\hline Triticum sp. & grain & & 4 & & 1 \\
\hline Cerealia indet. & grain & 21 & 12 & 15 & 1 \\
\hline Wild herbaceous plants & & & & & \\
\hline Chenopodium album & seed & 2 & 2 & & \\
\hline Galium cf. aparine & fruit & & 1 & & \\
\hline Lithospermum arvense & fruit & 1 & & & \\
\hline Bromus sp. & grain & 1 & 6 & 1 & 1 \\
\hline Galium sp. & fruit & & & 1 & \\
\hline Silene /Melandrium sp. & seed & 2 & & 1 & \\
\hline Stipa sp. & awn & 1 & & 1 & \\
\hline Vicia sp. & seed & & & & 1 \\
\hline Asteraceae & fruit & & & 1 & \\
\hline Brassicaceae & seed & & 1 & & \\
\hline Fabaceae & seed & & 1 & 1 & \\
\hline Fabaceae cf. Vicia sp. & seed & & 3 & & \\
\hline Panicoide & grain & 1 & & & \\
\hline Poaceae (large) & grain & 1 & & & \\
\hline Poaceae (small) & grain & & 1 & 1 & \\
\hline Vegetative parts of plants & part of stem? & 1 & & & \\
\hline Seed/fruit & seed/fruit & & 1 & & \\
\hline Undetermined & seed & 21 & 18 & 8 & 3 \\
\hline Trees and shrubs & & & & & \\
\hline Sambucus nigra & seed & & & & 1 \\
\hline Sambucus sp. & seed & & 1 & & \\
\hline Pinus sylvestris & wood & 2 & & & \\
\hline Betula sp. & wood & 2 & & & \\
\hline Quercus sp. & wood & 45 & 29 & 30 & 30 \\
\hline conifers & wood & 1 & & & \\
\hline broad-leaved & wood & & 1 & & \\
\hline
\end{tabular}


remains, which were sorted under a stereomicroscope and examined in order to make taxonomical identifications.

Taxa identification of fruits, seeds and chaff was based on observations of morphological features and their comparison with the reference collection available in the Department of Palaeobotany (IB PAS) and carpological atlases and specialist literature (KulPa 1974; RUtKowski 1998; LityŃsKa-ZająC, WASYlikowa 2005). A stereomicroscope with 10 and $16 \times$ magnifications was used. Only charred plant remains associated with the archaeological layers are interpreted as contemporaneous to archaeological material, although post-depositional mixing of materials of different ages cannot be ruled out. Uncharred materials found in typical, dry archaeological sites are considered modern contamination because in such sites unburnt organic materials usually disappear due to various actions of microorganisms (LITYŃSKA-ZAJĄC, WASYLIKOWA 2005).

Charcoal fragments were analysed by observing the anatomical structure of wood in the three anatomical sections (transverse, longitudinal tangential and longitudinal radial) under a reflected light microscope (Zeiss Axio Lab. A1). Botanical identifications were compared with anatomical atlases (e.g. SCHWEINGRUber 1990) and with a modern reference collection from the IB PAS. The taxonomical identification is mainly limited to genus level, but the identification to the species level is given in cases of a presence of solely one species from a genus in the present-day flora of the region (LiTYŃSKA-ZAJĄC, WASYLIKOWA 2005). The quantification method was based on fragment counts of charcoal remains (CHABAL 1997). Only fragments bigger than $1 \mathrm{~mm}$ in transverse section were analysed. Scanning electron microscopy (SEM) was also used for more detailed analysis of the fragments and for making X-ray microanalysis with the help of Energy Dispersive X-ray Spectroscopy (EDS) .

\section{RESULTS}

\section{Pottery}

Subjected to analysis were 754 fragments of pottery and six almost complete vessels. The largest series of pottery derive from features nos 2 and 5. Materials obtained from features nos 4 and 6 (pits containing burials) were mostly small and uncharacteristic fragments (see: Tab. 2). Based on typological and technological features of vessels, for more than one-third of the fragments it was possible to determine the form of vessel they derived from. In the analysed collection of pottery, baggy storage vessels and mugs prevail, but this does not reflect the real contribution of particular forms. Their domination results from easier identifiability of storage vessels (taking into account the technology of ceramic mass and the surface treatment) and mugs (they are usually fine forms - harder to be damaged or fragmented). At the same time, the proportions of bowls and amphoras seem to be significantly underestimated and the majority of "undetermined" potsherds should probably be linked with these two types of vessels. 
Table 2. Goszcza site 1. Number of typologically identified and undetermined fragments of pottery

\begin{tabular}{|l|c|c|c|c|c|}
\hline & Feat no. 2 & Feat. no. 4 & Feat. no. 5 & Feat. no. 6 & Total \\
\hline Storage vessels & 107 & & 56 & 3 & 166 \\
\hline Mugs & 49 & 1 & 80 & & 130 \\
\hline Bowls & 17 & & 6 & 2 & 25 \\
\hline Amphorae & 16 & & 12 & & 28 \\
\hline Unidentified & 248 & 2 & 133 & 22 & 405 \\
\hline Spindle whorls & 6 & & & & 6 \\
\hline Total & 443 & 3 & 287 & 27 & 760 \\
\hline
\end{tabular}

The most common type of baggy storage vessels is those with brush-smeared bodies (Fig. 7: a, d, k). They occur in two forms: the first one with a notched cordon below the rim (Fig. 7: c, e, f, h) and cone-shaped knobs (Fig. 7: g, i) and the second decorated only with knobs (Fig. 7: a, b, j).

In the discussed collection, the share of mugs with handles protruding above the rim is significant as well. Three variants of such vessels were distinguished at the site. The first form is represented by mugs with rounded bases and spherical bodies, sometimes with slightly out-turned rims (Fig. 8: a-f) - some of them have bodies decorated with vertical grooves (Fig. 8: a, b, e) or handles (Fig. 8: c, d). In several cases, grooves are accompanied by impressed or stamped ornamentation. The second type comprises relatively large mugs with a flat base, a low-placed widest part, and a ribbon handle protruding above the rim. This type is represented by a reconstructed vessel deriving from the bottom of feature no. 5 and a fragment from the ceiling part of the same pit. In both cases, their bodies and handles were decorated with wide grooves. The last type of mugs comprises exemplars with rounded bases, with slightly marked profiling of the body (Fig. 8: h, i, k, 1). The vessels of this group were ornamented exclusively with stamp impressions and imprints.

Bowls comprise another type of vessel identified at Goszcza 1, represented by two variants: conical (Figs 4: d, 9: b, d) and hemispherical bowls with slightly in-turned rims (Fig. 9: a, c, e, f, g). Their bodies are usually decorated with motifs of "hanging triangles" and plastic cordons located under the rim; rims of these vessels are fingertipped or notched. A noteworthy exemplar is a conical bowl from feature no. 5 with a small ribbon handle (Fig. 9: d). Its outer walls are decorated with mixed ornamentation of imprints and "hanging triangles". Some fragments with tongue-shaped protrusions on the rims, and those with horizontally pierced handles set below the rim should also be included in the group of bowls.

Amphoras comprise the last group of vessels. They are represented, among others, by a well-preserved vessel from the bottom of feature no. 2 and a nearly completely reconstructed one from feature no. 5. The amphora from feature no. 2 (Fig. 10: a) is a spherical vessel decorated with three vertically pierced handles attached to the widest part of the body. It has a short, cylindrical neck and an emphasized base. It is $18.5 \mathrm{~cm}$ high, with a base diameter of $18.5 \mathrm{~cm}$ and a rim diameter of $12.5 \mathrm{~cm}$. It is ornamented with a notched plastic cordon attached horizontally at the transition between the neck 

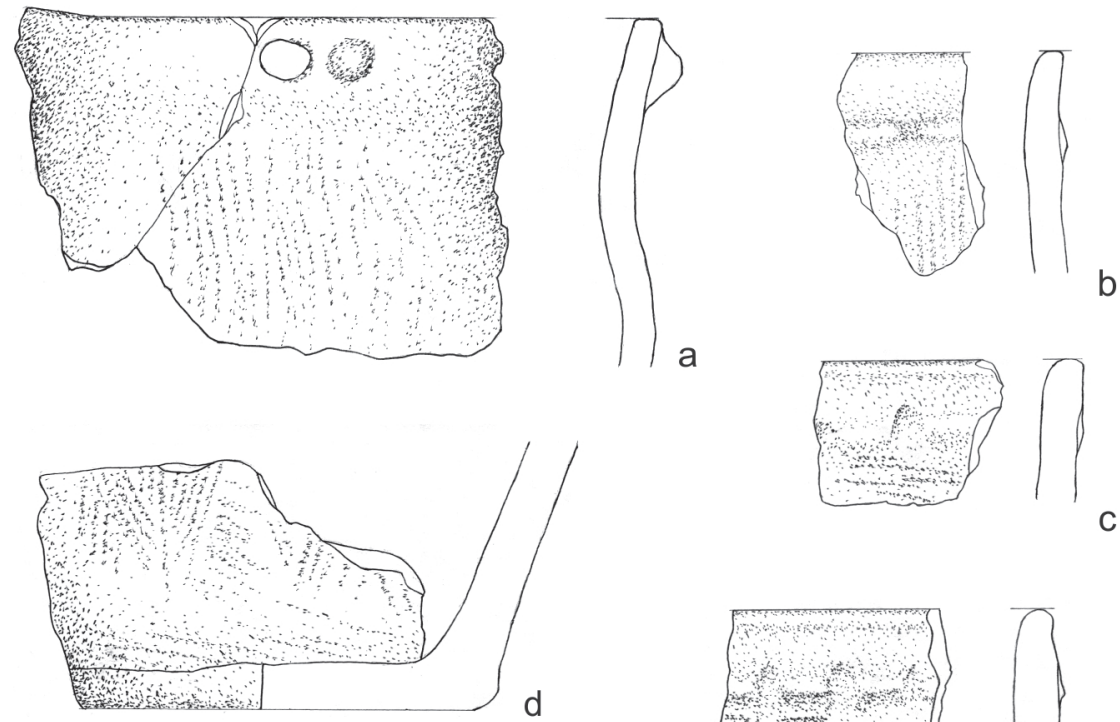

C
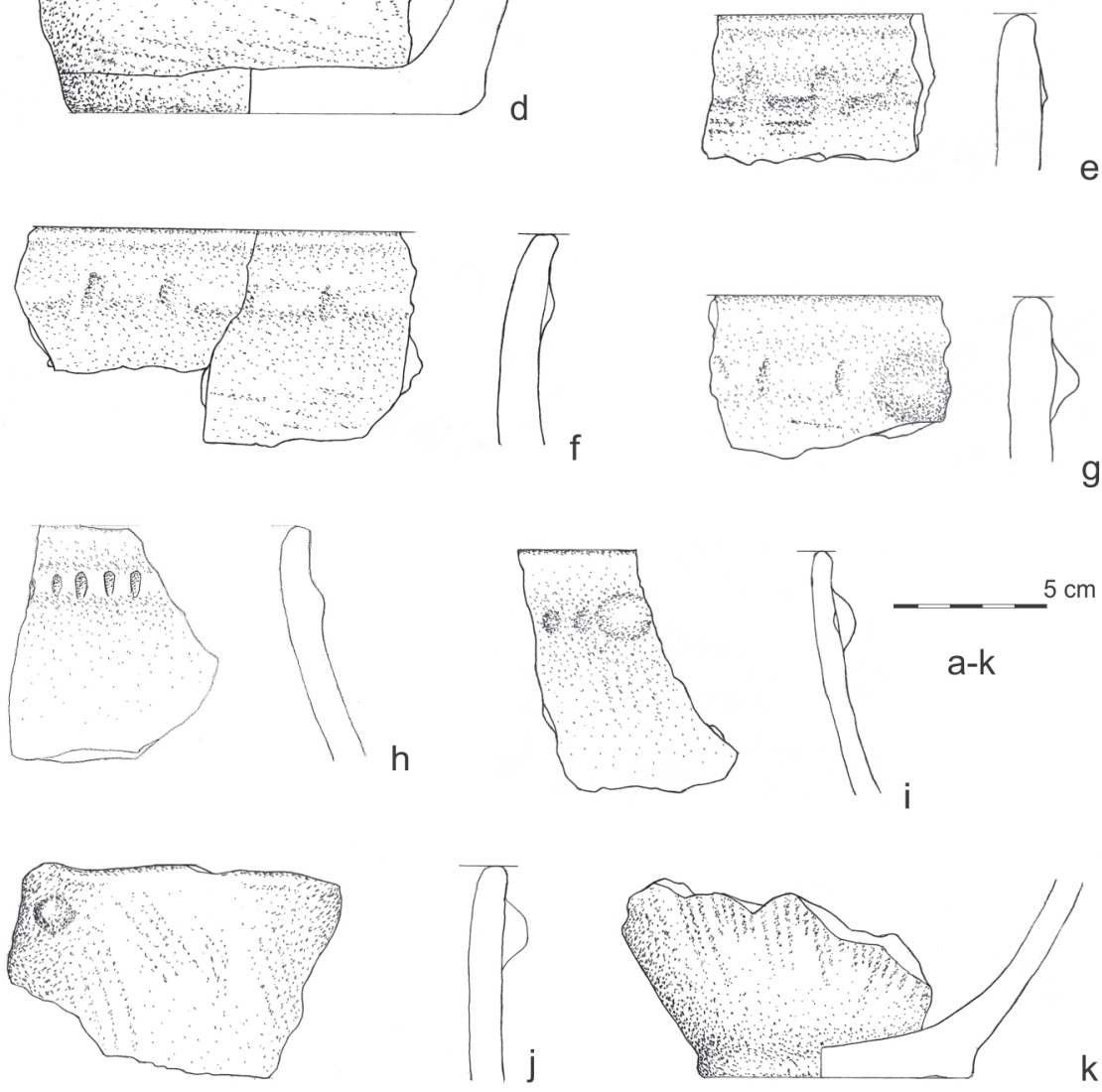

Fig. 7. Goszcza site 1. Characteristic fragments of storage vessels. Drawn by W. Rumian

and the body; other notched cordons run vertically from the horizontal one down the vessel's body. Another amphora derives from feature no. 5 (Fig. 10: b). It is a vessel with a spherical body gently passing into a slightly flaring neck. The widest part of the 

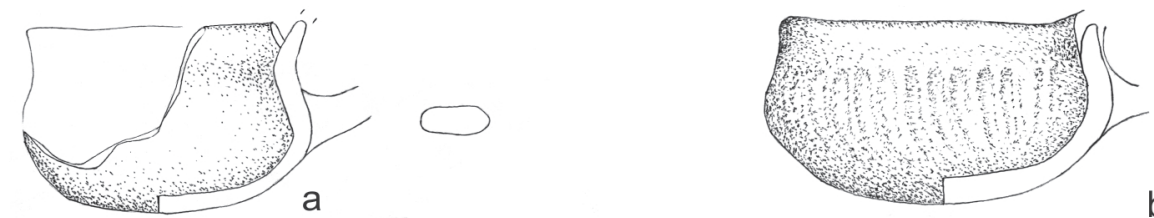

b
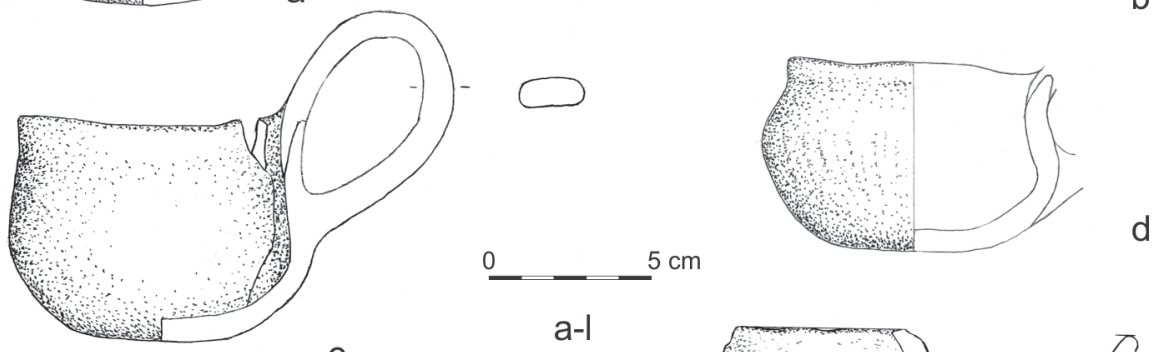

d

C
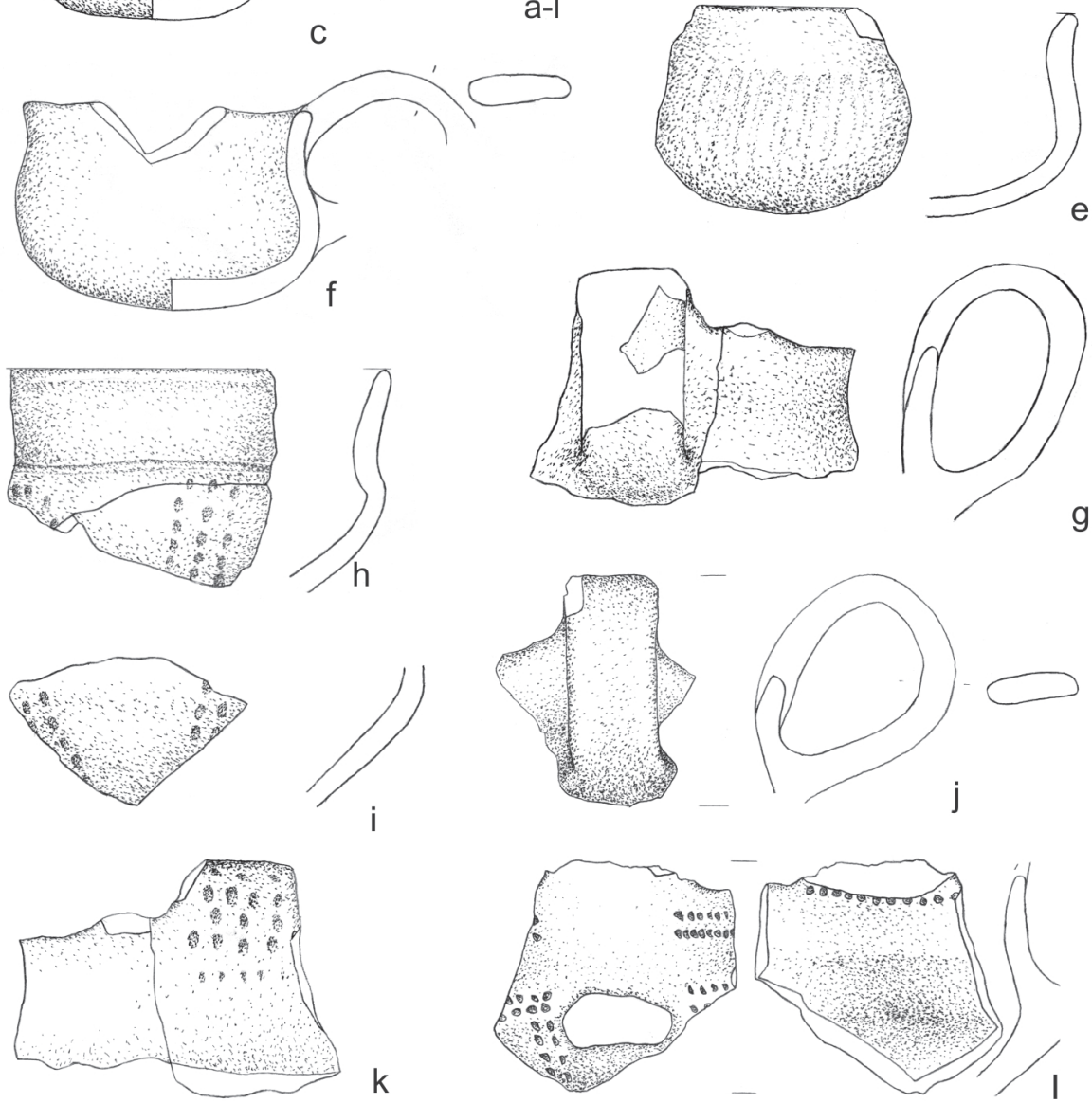

Fig. 8. Goszcza site 1. Characteristic fragments of mugs. Drawn by W. Rumian

body is decorated with two vertically pierced handles which in their upper parts pass into curved, elongated notched cordons. The base of the amphora is well-defined and flat. The vessel is $13 \mathrm{~cm}$ high; the diameter of the base is $6.5 \mathrm{~cm}$, and the diameter of the rim is $9 \mathrm{~cm}$. It is decorated with a horizontal notched cordon located at the 

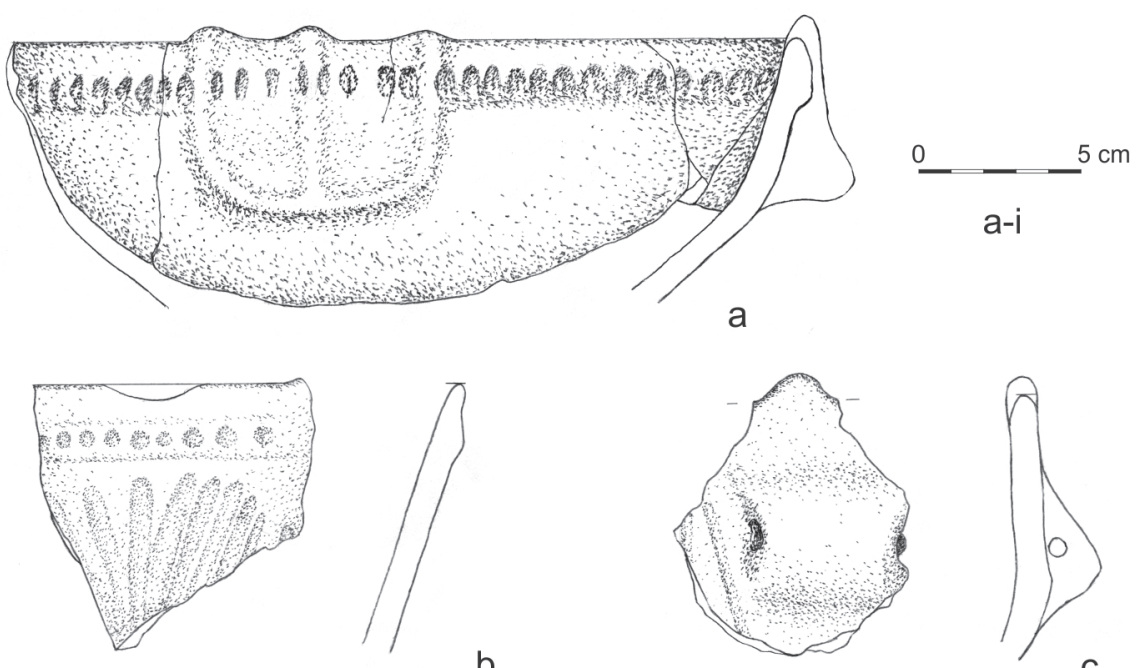

b

$\mathrm{C}$
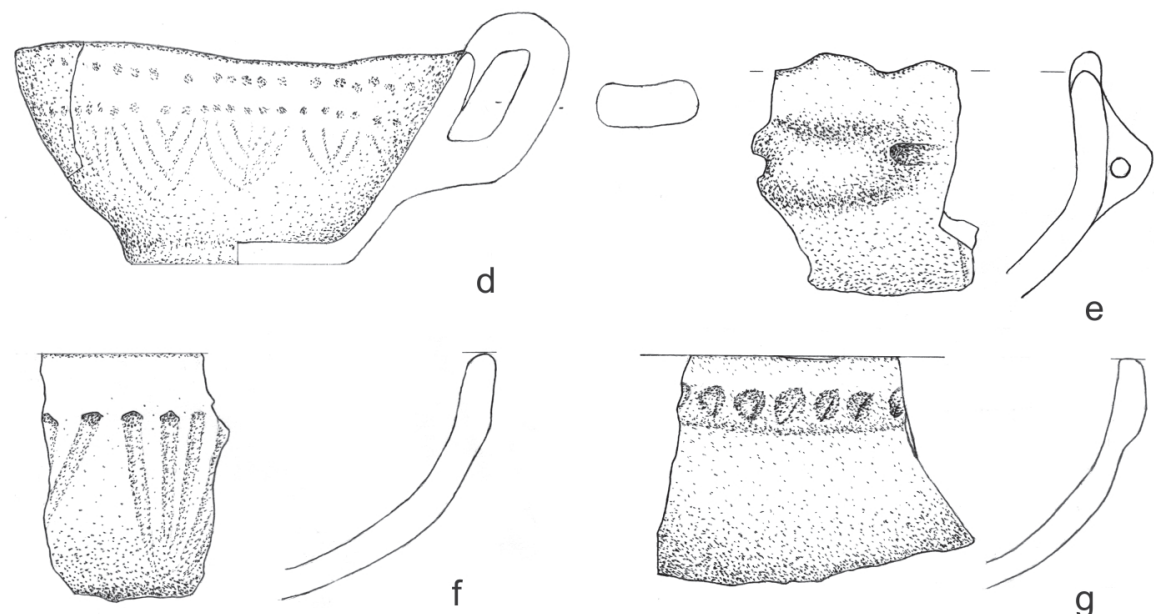

g
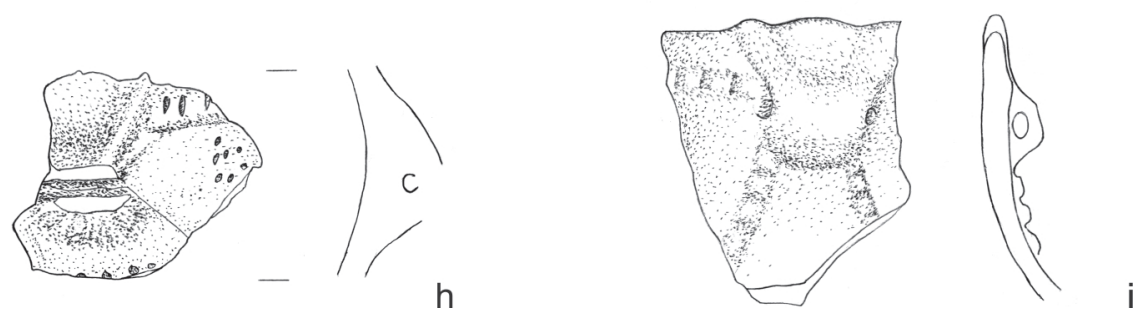

Fig. 9. Goszcza site 1. Characteristic fragments of bowls (a-g) and amphorae (h-i). Drawn by W. Rumian base of the neck, below which are vertical grooves, in some places interspersed with diagonal incisions (this vessel was originally probably decorated with "hanging triangles" and only later covered with vertical grooves). Another fragment of an amphora was found in the same feature - it derives from a vessel with a pear-shaped body and 

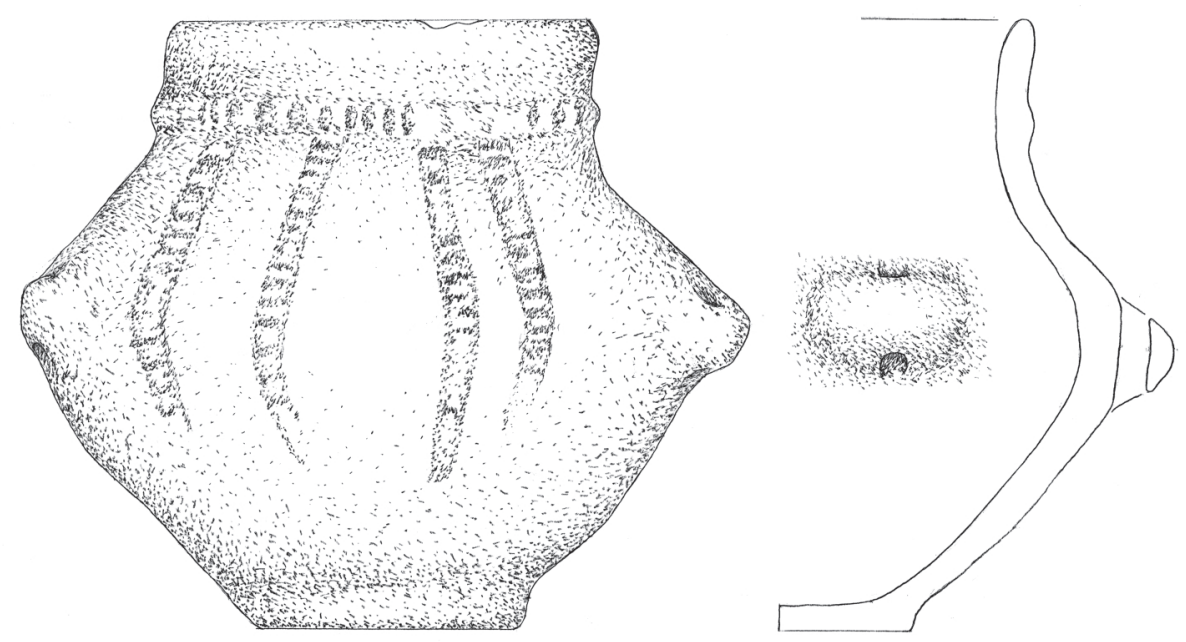

a
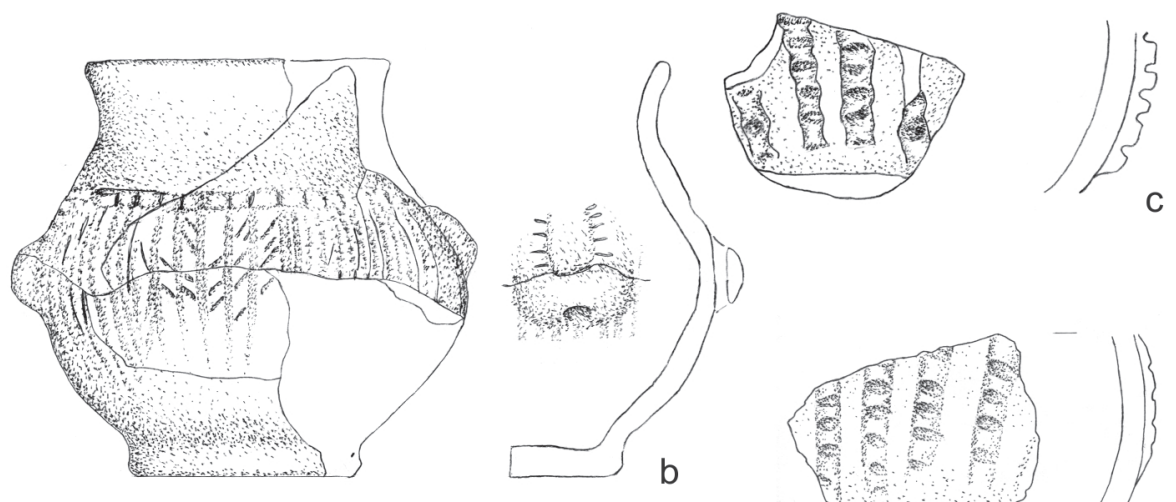

C
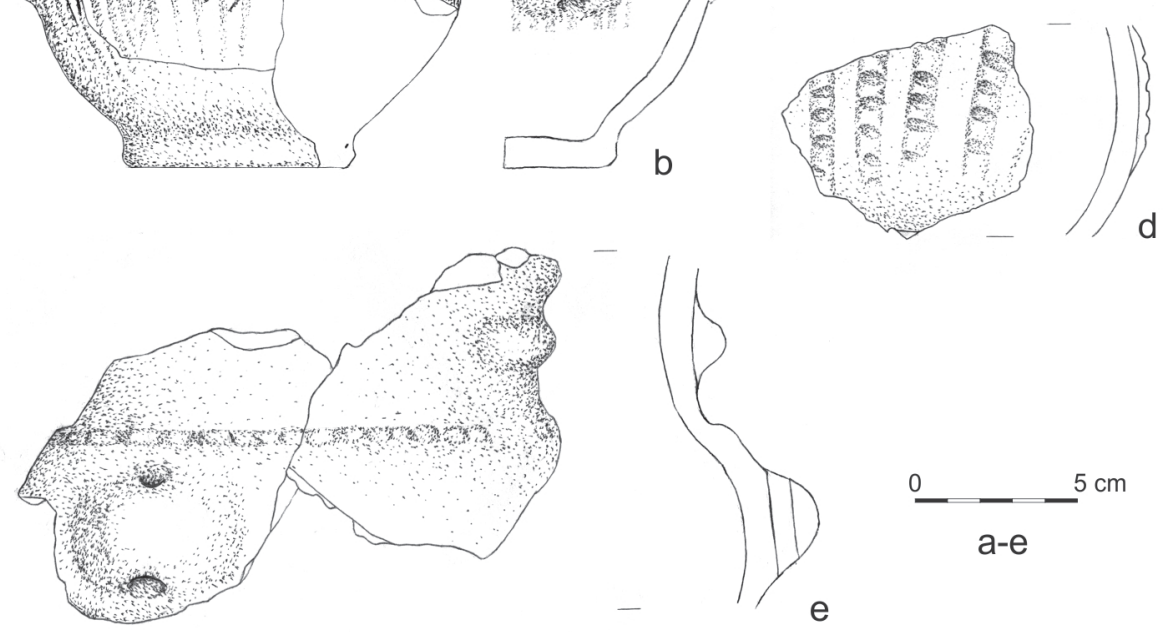

Fig. 10. Goszcza site 1. Characteristic fragments of amphorae. Drawn by W. Rumian

a well-defined cylindrical neck (analogies - amphora of the A type from Zesławice) (GoDŁOWSKA 1968; Bober 2015). It is decorated with notched cordons: one horizontal and several arranged vertically, and the body is covered with dense, vertical grooves while its neck is decorated with "hanging triangles" (Fig. 11: a). Remaining sherds 

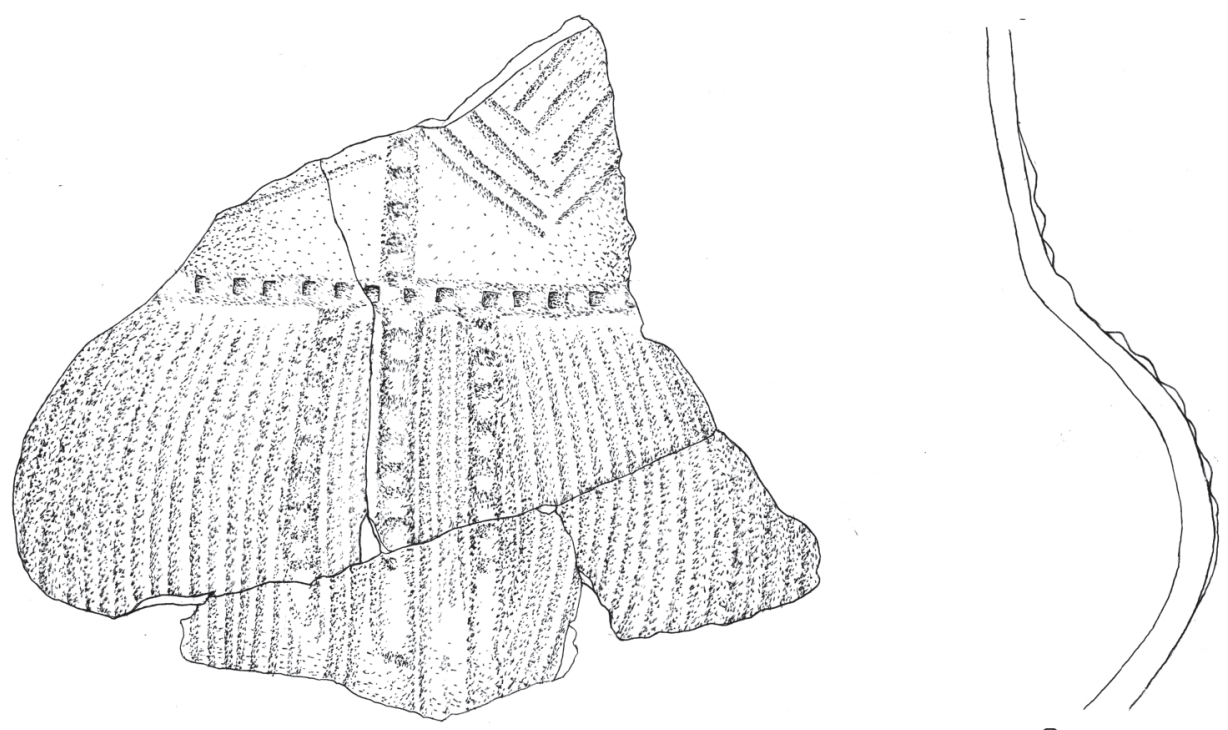

a
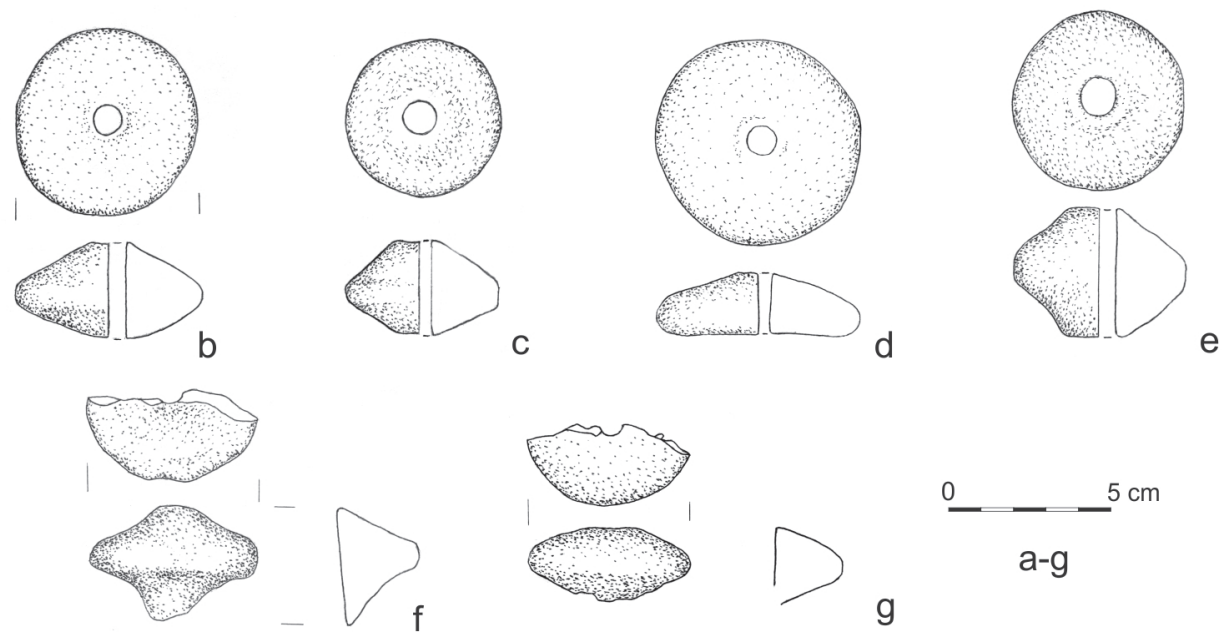

Fig. 11. Goszcza site 1. Characteristic fragments of an amphora (a) and spindle whorls (b-g).

Drawn by W. Rumian

classed as amphoras are several body fragments decorated with horizontal plastic cordons (Fig. 10: c, d), fragments of rims (Fig. 9: h, i), and shoulders (Fig. 10: e).

Ornamented fragments constitute $65 \%$ of the analysed materials and some basic types of ornamentation can be distinguished, including grooved decoration, "hanging triangles", stamped ornamentation, plastic decoration, impressed ornamentation, and traces of smearing or coarsening (regarded as technical manipulations rather than decoration). They occur in various combinations and motifs.

A separate group of artefacts is comprised of spindle whorls and their fragments (6 specimens) deriving exclusively from feature no. 2. These are: one lentoid spindle 
whorl (Fig. 11: d), three biconical spindle whorls (Fig. 11: b, c, e) and two fragments of undetermined type (Fig. 11: f, g). None of them were ornamented.

\section{Stone industries}

55 flint artefacts and one quern made of sandstone (from feature no. 6) were subjected to analysis. Flint artefacts derived mainly from features nos 2 and 5, with only a small series recovered from pit no. 6. The majority of artefacts were made from Kraków Jurassic flint and from flint of the $G$ variant. Raw materials of the remaining specimens could not be determined due to their secondary burning.

Flakes are represented by 32 artefacts. This number includes flakes resulting from damage, repair or reutilization of tetrahedral axes made of flint of the $G$ type. There are seven such flakes, including a broken cutting-edge part of an axe.

Blades and their fragments are represented almost exclusively by artefacts made of Jurassic flint (apart from two burnt specimens). They are of mediolithic character. They are mainly proximal fragments.

Five artefacts discovered at the site were identified as tools, including (1) an endscraper with a narrow and straight end-scraper front on a broken distal end of a blade (G variant) (Fig. 12: b), (2) an end-scraper on a crested blade with a semicircular end-scraper front in a distal part and fine retouch on one of the edges (G variant) (Fig. 12: d), (3) a proximal fragment of a broken blade with a truncated base and abrupt and semi-abrupt retouch of edges and plane alternating retouch on ventral side
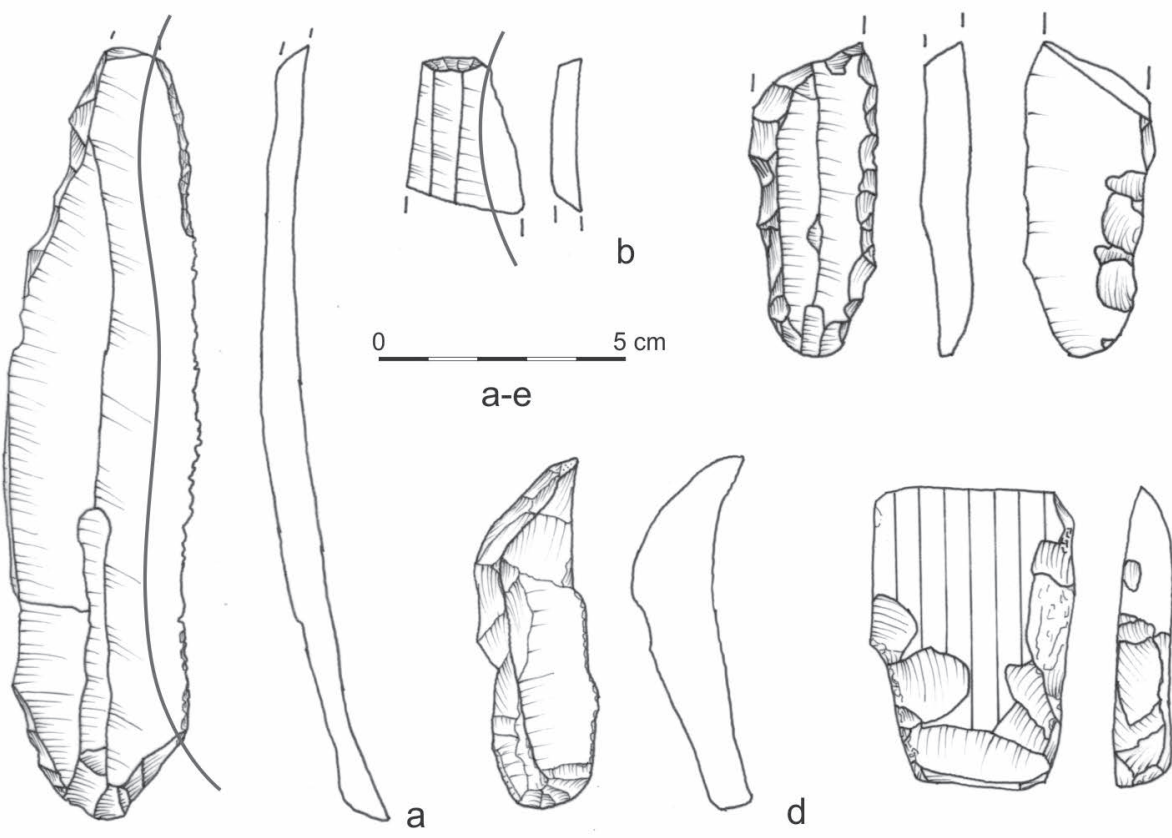

C
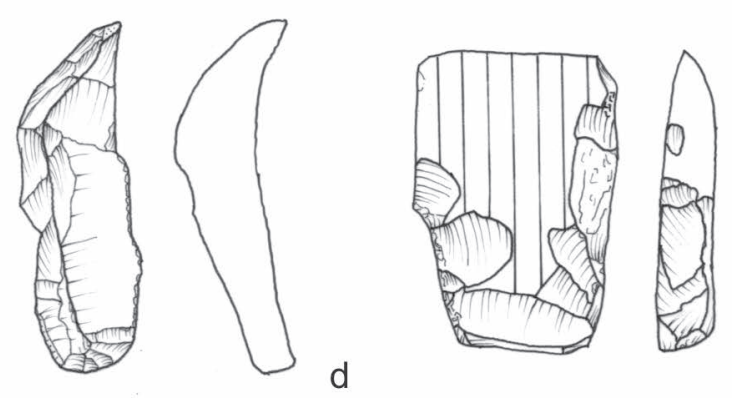

Fig. 12. Goszcza site 1. Characteristic flint artefacts. Drawn by M. Nowak 
of the blade (G variant) Fig. 12: c), (4) a sickle-blade on a long blade with a base formed into a tang - in its distal part there is an oblique backed edge with a broken end; the working edge of this sickle blade is covered with fine denticulate retouch and lengthwise harvesting polish (G variant) (Fig. 12: a), (5) a tetrahedral axe made from Kraków Jurassic flint (Fig. 12: e).

\section{Bone tools}

A separate category comprises tools, ornaments and semi-products made from bone and animal teeth, which are represented in this assemblage by nine objects. Among them, six items can be identified to a species level, and the remaining three have been transformed by humans to a degree making species identification impossible.

Two awls were made from distal parts of cattle metapodia (Fig. 13: a) and distal parts of pig tibias (Fig. 13: b). While modification of pig bones was limited only to breaking the bone, treatment of cattle metapodia was more complicated and required splitting of the bone, careful bone edge grinding and preparation of the working part. The working tips of both awls bear signs of intensive scraping and smoothing, partly created during their use. A bone chisel was made on a distal part of a cattle metapodium (Fig. 13: d). After longitudinal splitting the bone was strongly modified by grinding of the internal bone side, forming a strongly flattened and narrow working edge. In the inventory a small part of a bone spatula, made on a large mammal (cattle?) rib was discovered. It has a strongly smoothed internal surface, created during the bone splitting. In the analysed inventory, two fragments of adornments were identified. They were made from wild boar lower canine teeth and bear marks of scraping and smoothing. The single fragment has partially damaged drilled perforations (Fig. 13: c). The remaining modified bones represent waste or fragments of unidentified/unfinished bone tools, represented by a proximal part of cattle metapodium and two bone fragments of a large mammal.

\section{Anthropological analysis of human skeletal remains}

Bone preservation of human remains from feature no. 6 is good. The following elements are present: the skull and mandible (Figs 14, 15), both scapulae, both clavicles, both humeri, both ulnas, the radius, carpal bones, metacarpals, phalanges, cervical vertebrae, thoracic vertebrae (apart from T1 and T2), lumbar vertebrae, sacrum, both femurs, both tibia, both fibulas, heel bones, anklebones, incomplete metatarsal bones, and phalanges of foot. The skull is delicate with a high forehead, emphasized frontal tubers, faint superciliary arches, protruding occiput, high rounded orbits and small mastoids. The muscle attachments of the occipital bone have tender build. Cranial sutures are open, with no tendency to cranial suture closure. In the left part of the lambdoid suture, there is a little Wormian bone. The postcranial skeleton has a delicate and tender build. The pelvis is wide with an obtuse subpubic angle. Both tibias are arched forward. The right humerus has adnate epiphyses: the adnate distal epiphysis and open proximal epiphysis. Both radii have closed proximal epiphyses, and distal epiphyses are open. Both ulnas 

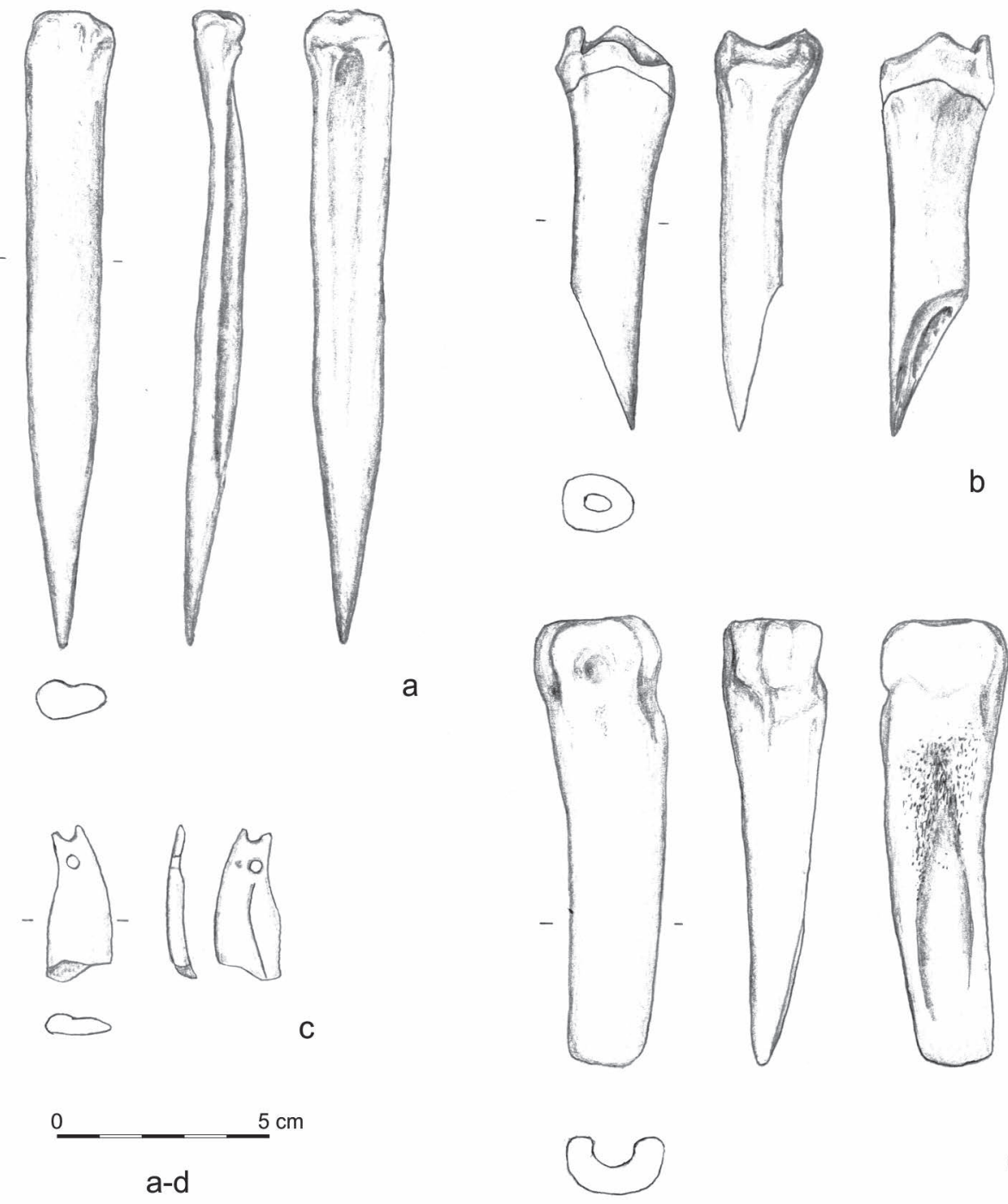

b

a
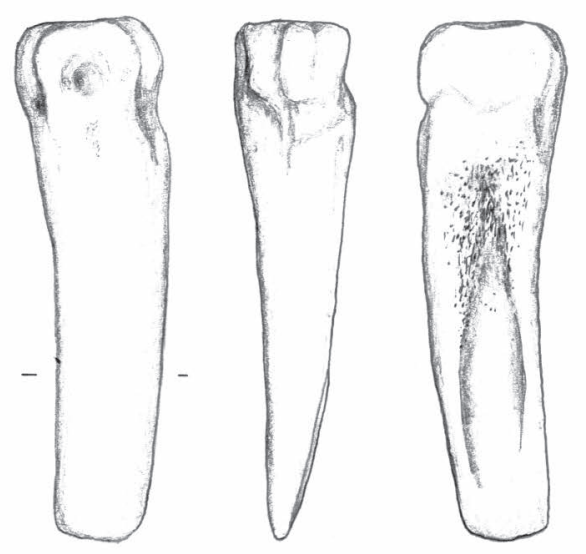

d

Fig. 13. Goszcza site 1. Characteristic bone artefacts. A - awl made of cattle metapodium, $b$ - awl made of pig tibia, $\mathrm{c}$ - fragment of ornament made of wild boar lower canine, $\mathrm{d}$ - chisel made of cattle metapodium Drawn by W. Rumian

have closed proximal epiphyses, whereas distal epiphyses are open. Capituli of thigh bones are adnate; distal epiphyses are open. Distal and proximal epiphyses of tibias are in the early phase of accretion. Epiphyses of fibulas are open. Based on the stage of union between epiphyses and diaphyses of long bones, the age of the individual is estimated as late juvenis (about 17-19 years old). On account of the young age of the individual, determination of sex is problematic - on the basis of the pelvis, we may estimate it is a female skeleton. In the lumbare spine column, we may notice spinal injuries: hernias, disc syndrome and degenerative changes of the marginal bone superstructure 


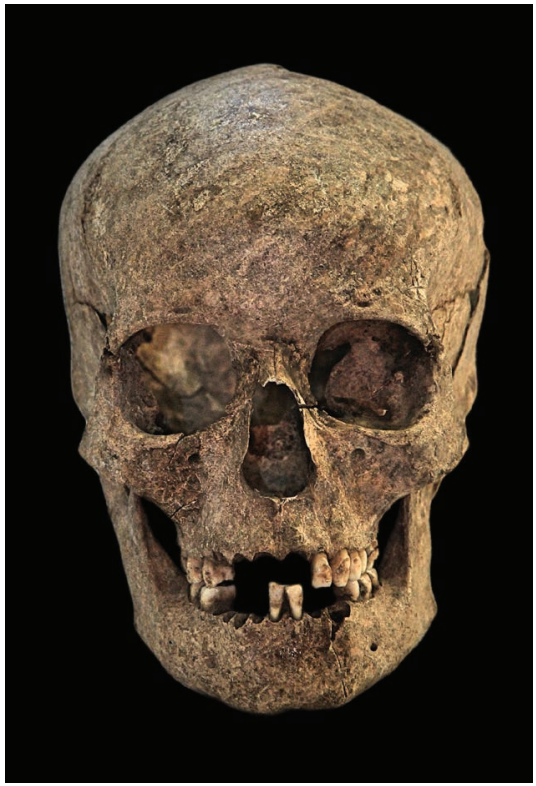

Fig. 14. Goszcza site 1. Skull of individual from feature no. 6 - frontal view. Photo by J. Wróbel

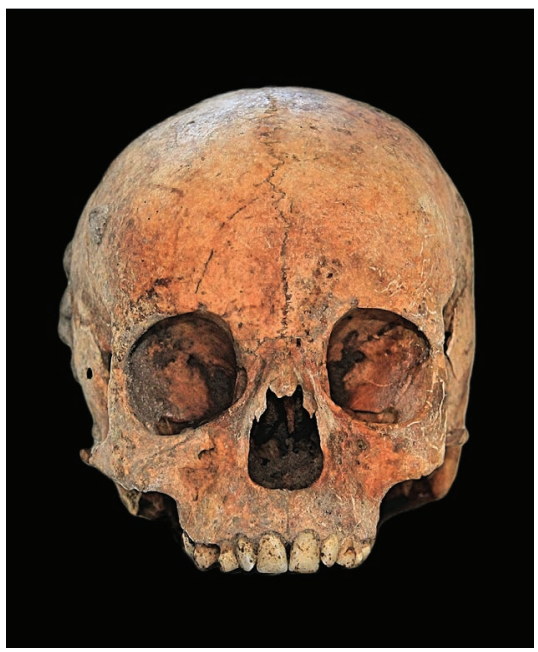

Fig. 16. Goszcza site 1. Skull of individual from feature no. 4 - frontal view. Photo by J. Wróbel

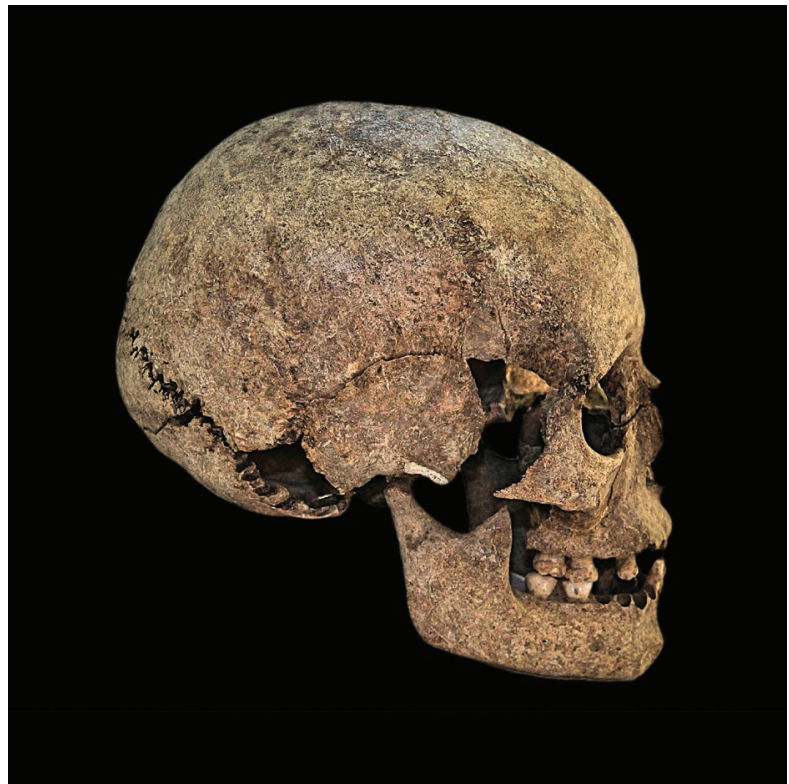

Fig. 15. Goszcza site 1. Skull of individual from feature no. 6 - lateral view. Photo by J. Wróbel

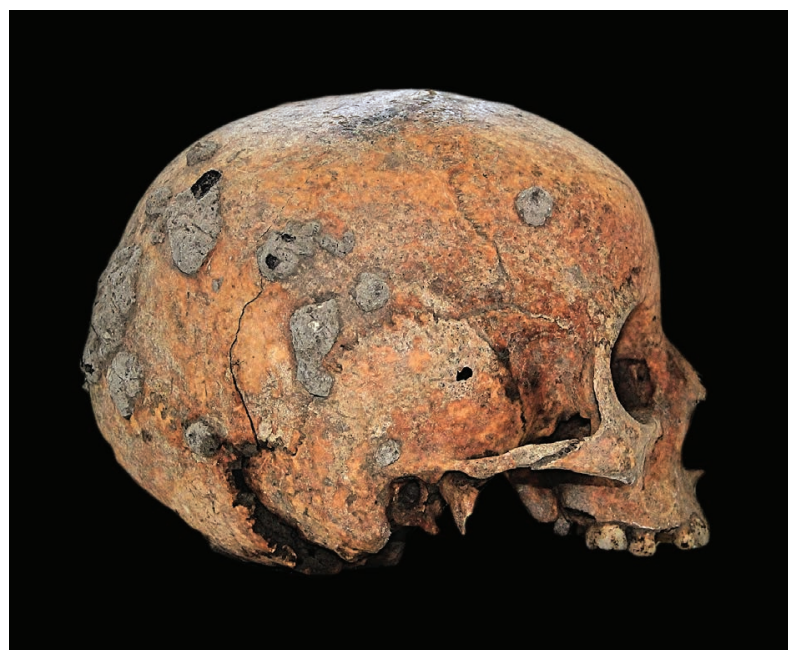

Fig. 17. Goszcza site 1. Skull of individual from feature no. 4 - lateral view. Photo by J. Wróbel

(osteophytes). Tibias are arched outwards (bowlegs) - such an effect may result from numerous causes, most often from rickets resulting from vitamin D deficiency.

The second hypothetical burial of the Baden culture in feature no. 4 is represented by a well-preserved skeleton. The following elements are present: the skull (Figs 16, 17) and 
mandible, scapulas, clavicles, humeri, ulnas, radial bones, wrist bones, metacarpal bones, phalanges, cervical vertebrae, thoracic vertebrae, lumbar vertebrae, the sacrum, thigh bones, tibias, patellae, fibulas, heel bones, talus bones, metatarsal bones, and phalanges of feet. The skull is quite long and narrow with huge orbits and a rounded occipital bone. In the Bregma point, there is a little Wormian bone. The frontal bone has non-connate metopic suture (sutura metopica). Over the distal epiphysis of the humerus, an ossified muscle attachment is noticeable. In the mandible and jaw, permanent incisors and molars M1 are erupted. In both jaws there is a set of primary molars and canines. The age of this individual may be estimated as infans II (circa 9-10 years old - based on the stage of teeth eruption). No pathological changes are observed.

Apart from the discoveries described above, in humus over feature no. 2 the distal epiphysis of a humerus was found. It derives from an individual aged 10 to 14 years (infans II - based on the measurements of the epiphysis).

\section{Animal remains}

The animal remains discovered at Goszcza site are well preserved; only single bones bear signs of root etching or weathering. They were discovered in three features, whereas single animal bones found in burial number 6 can be interpreted as unintended admixture - these remains probably were deposited into the grave-pit together with the burial filling.

Animal bones and teeth belong to a minimum of nine species, representing both domesticated and wild mammals (Tab. 3). Among them remains of cattle, goat/sheep and pig clearly predominate. Noteworthy are goat/sheep remains, representing a minimum of four individuals, of which three were less than 1.5 years old at the moment of death. Also

Table 3. Goszcza site 1. Number of identified bones (NISP) and minimal number of individuals (MNI) of animal species

\begin{tabular}{|c|c|c|c|c|c|c|c|c|c|c|c|c|}
\hline Feature & 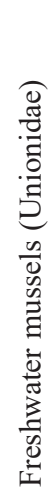 & 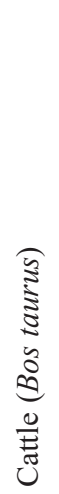 & 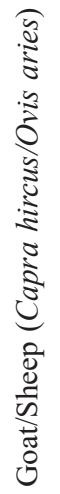 & 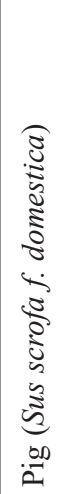 & 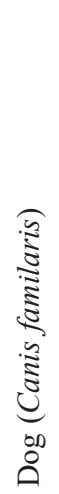 & 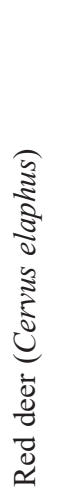 & 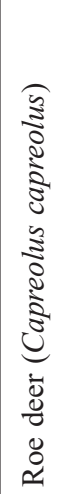 & 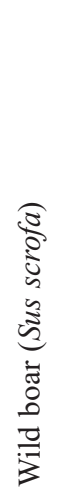 & 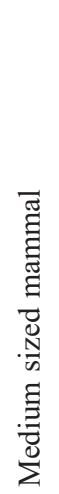 & 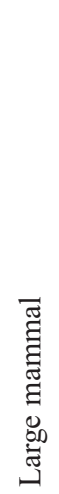 & 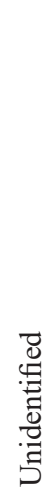 & Total \\
\hline 2 & & 33 & 23 & 19 & 6 & - & - & 2 & 76 & 77 & 52 & 288 \\
\hline 5 & 1 & 6 & 11 & 10 & - & 1 & 1 & 3 & 20 & 15 & 7 & 75 \\
\hline 0 & - & - & 2 & - & - & - & - & - & - & - & - & 2 \\
\hline Total NISP & 1 & 39 & 36 & 29 & 6 & 1 & 1 & 5 & 96 & 92 & 59 & 365 \\
\hline Total MNI & 1 & 2 & 4 & 2 & 2 & 1 & 1 & 1 & - & - & - & 14 \\
\hline
\end{tabular}


significant, sparse dog remains are represented by a minimum of two adult individuals. The wild mammals assemblage, although scarce in numbers, is quite diversified and represents typical game species like red deer, roe deer and wild boar (Tab. 3).

Remains of different body parts (skull, axial skeleton, long bones, distal part of the limbs) of both domesticated and wild species were discovered. On them, many traces of human activity are visible. We identified cut marks that can be interpreted as a result of dismembering $(\mathrm{N}=9)$ and filleting $(\mathrm{N}=4)$ of the animal's body (Fig. 18: 2, 3). They occur on cattle $(\mathrm{N}=5)$, pig $(\mathrm{N}=5)$, goat/sheep $(\mathrm{N}=2)$ and large mammal $(\mathrm{N}=1)$ bones. Further, five bones bear traces similar to chop marks. They are visible on a cattle astragalus, two ribs and, surprisingly, on a skull and a humerus of dog. Clear punch marks visible on long bones, created during marrow extraction, were observed on cattle and red deer remains (Fig. 18: 1). Additionally, two bones of cattle bear marks of burning. Some animal body parts were also used for production of tools and ornaments.

In the discussed assemblage 43 bones bear marks of dog gnawing (Fig. 18: 4). They were especially frequent on goat/sheep $(\mathrm{N}=15)$, pig $(\mathrm{N}=7)$, and medium mammal $(\mathrm{N}=17)$ bones. Surprisingly, this kind of traces are observed only on single cattle $(\mathrm{N}=2)$ and large mammal $(\mathrm{N}=1)$ bones. Additionally, a single proximal phalanx of pig was digested.

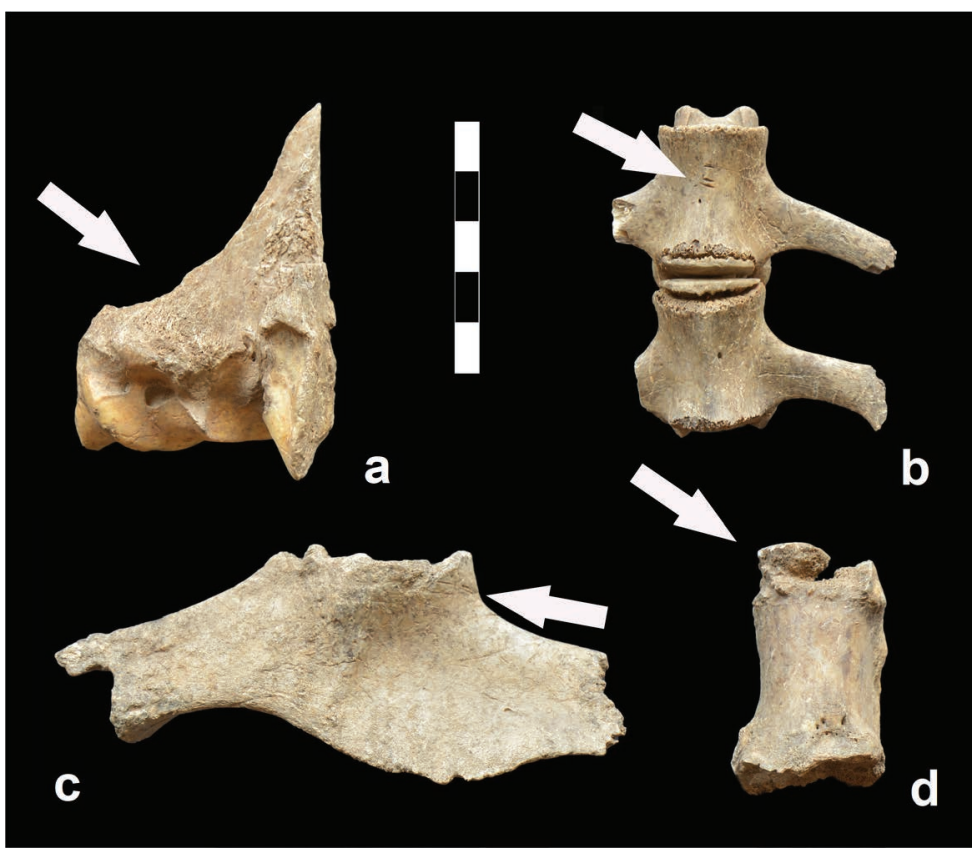

Fig. 18. Goszcza site 1. Animal remains. a - red deer, distal part of radius with punch mark, b - goat/ sheep, lumbar vertebra with oblique cut marks, c - pig, pelvis with transversal cut marks and gnawing marks visible on both ends, $\mathrm{d}-$ cattle, proximal phalanx with gnawing marks. Photo by J. Wilczyński 
Plant remains

Fruits and seeds

Among charred plant macro-remains, 20 taxa were distinguished in the material: eight were identified to the level of species: Chenopodium album, Galium cf. aparine, Lithospermum arvense, Sambucus nigra, Triticum turgidum L. ssp. dicoccum (Schrank) Thell. (=T. dicoccon, T. dicoccum), T. monococcum L. ssp. monococcum $(=T$. monococcum); seven to the genus level: Bromus sp., Galium sp., Sambucus sp., Silene/ Melandrium sp., Stipa sp., Triticum sp., Vicia sp.; six to the family level (Asteraceae, Brassicaceae, Cerealia, Fabaceae, Paniceae and Poaceae (Tab. 1, Figs 19 and 20).

The macroscopic plant remains included various types of plants such as crops, mostly cereals and wild herbaceous and woody plants (Tab. 1). The majority of macroscopic plant remains came from two samples from feature no. 5, but in feature no. 6 the plant assemblage was also quite numerous. At the bottom of feature 2, plant remains appeared with lesser frequency.

a

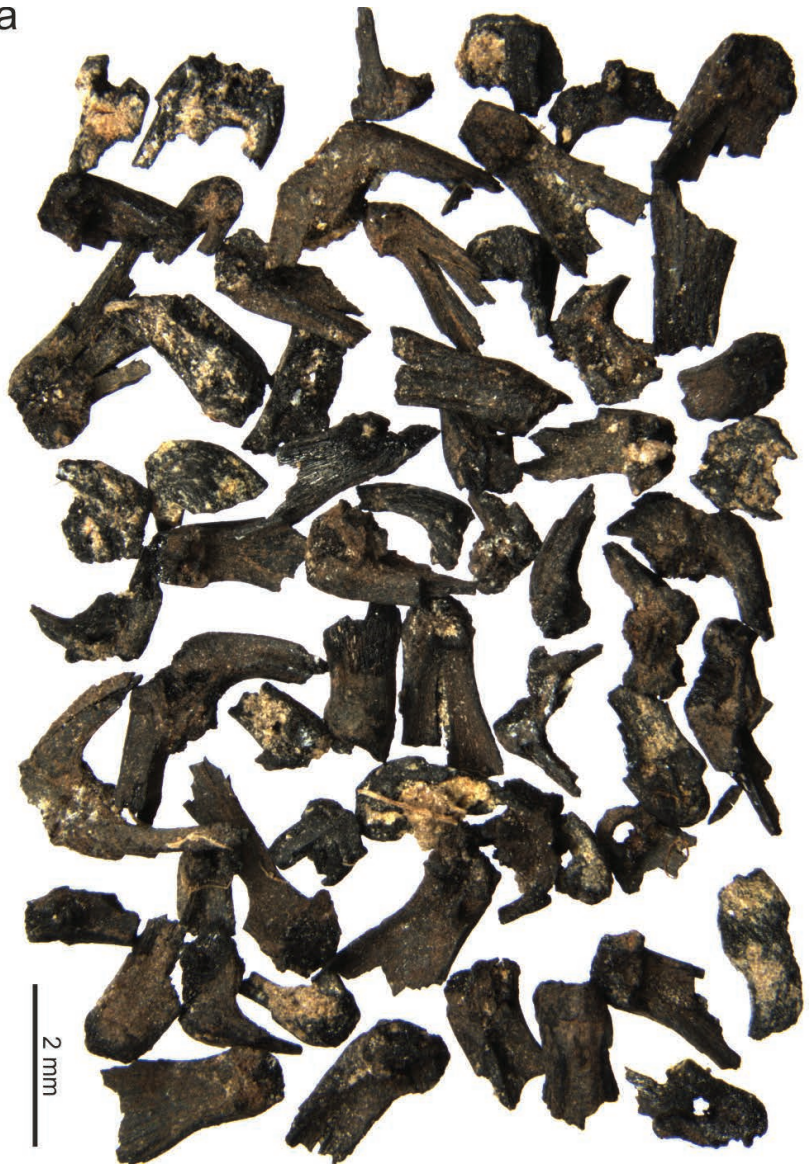

b

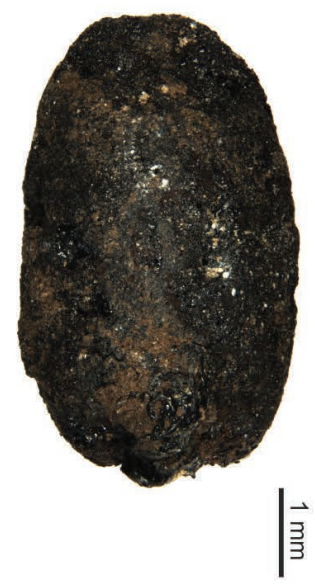

C

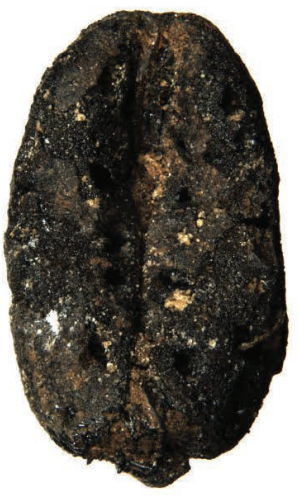

Fig. 19. Goszcza site 1. Remains of cultivated plants: Triticum dicoccum chaff (a) and grains (b-c). Photos by K. Stachowicz 

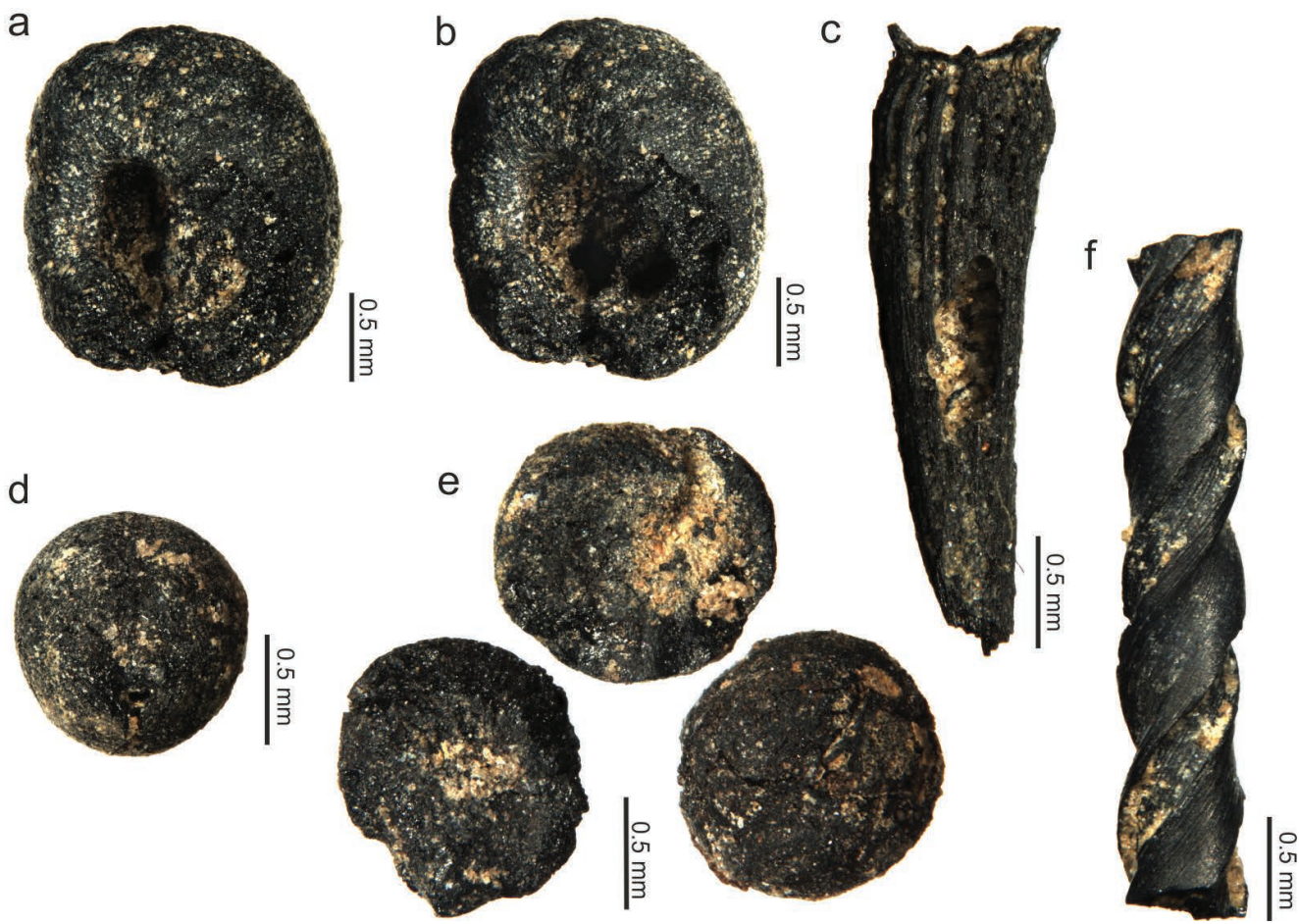

Fig. 20. Goszcza site 1. Remains of wild growing plants: Galium cf. aparine (a-b), Asteraceae (c), Brassicaceae (d), Fabaceae cf. Vicia (e), Stipa sp. awn (f). Photos by K. Stachowicz

Crops are represented by chaff remains of glumed wheats such as emmer wheat (Triticum diccocum) and einkorn wheat (Triticum monococcum) (Fig. 19: a), and by remains of grains (Fig. 19: b, c). Wheats are also represented by fragments of caryopses, whose state of preservation does not allow for determination to the level of species (Triticum sp.). The seeds of vetch (Vicia sp.) most likely also represent crops, although their condition does not permit further determination to the species level. Depending on the species, vetch can be a crop or a wild plant. In sub-fossil materials it is difficult to determine whether we are dealing with vetch or wild vetch, because the size of the seeds is similar in both forms (LITYŃSKA-ZAJĄC, WASYLIKOWA 2005). Among other taxa, plants typical for open landscapes (including cereal weeds), meadows, and ruderal landscapes are represented by Silene sp. or Melandrium sp., Galium sp., Galium cf. aparine (Fig. 20: a, b), goosefoot Chenopodium type album, and field gromwell Lithospermum arvense. Also, grasses were documented in the carpological materials, such as brome grass (Bromus sp.), feather grass Stipa sp. (Fig. 20: f) preserved in the form of awns, and the Poaceae family, represented by large and small caryopses. Only well-preserved seeds can be determined to the level of species, while fragments lacking species-specific characteristics should be identified to the level of genus. Specimens that have been identified to the family level have features characteristic for a given taxonomic group, but they lack diagnostic features that allow them to be 
clearly determined to the level of species or genus (i.e. cf. Vicia sp. of the Fabaceae family: Fig. 20: e). For example, this can be observed in the case of a specimen from the Asteraceae family (Fig. 20: c), which was identified based on the sculpture and the remains of the pappus. In contrast, a specimen from the Brassicaceae family is similar in shape and size to Brassica rapa (Fig. 20: d). However, the lack of features of the sculpture and the damaged hilum did not allow for further identification. Due to the poor preservation, several seed specimens could not be determined (Tab. 1: undetermined). Finally, one seed of elderberry (Sambucus nigra) was found, but it is very likely that another fragment of a seed, which was determined only to the level of genus (Sambucus sp.), may also represent this shrub or coral lilac (Sambucus racemosa), which has seeds very similar to elderberry (LiTYŃsKa-ZAJĄC 2005).

There were numerous uncharred goosefoot seeds (Chenopodium type album), which were not included in the list of prehistoric plant remains because they probably have younger origin (MUELLER-BIENIEK et al. 2018).

\section{Wood remains}

Charcoal fragments were small $\left(1-2 \mathrm{~mm}^{3}\right)$ and in poor states of preservation. The majority of them were strongly vitrified (Fig. 21: a, e, f) and calcified as confirmed by X-ray microanalysis (Fig. 21: b, c). Among 140 charcoal fragments, only three taxa were documented, identified to species (Scots pine Pinus sylvestris) and genus (oak Quercus sp. and birch Betula sp.). A few fragments were only identified as belonging to coniferous and broad-leaved trees or shrubs. Quercus sp. is a dominant taxon found in all samples, while other taxa were found sporadically in one sample coming from feature no. 5. In general, the charcoals were too small to observe whether they came from wood of trunks or from branchwood, based on the ring curvature (MARGUERIE, HunOT 2007). A few fragments showed the presence of fungi and were characterized by cellular collapse, which means that they could have come from decayed deadwood (Moskal-Del Hoyo et al. 2010).

\section{DISCUSSION}

During the last three decades, settlement and chronology of the Baden culture in the Kraków region has been the subject of numerous analyses (i.e. ZASTAWNY 1999, 2000, 2006, 2015a, b). The processing and production of flint tools has been investigated as well (Trela-Kieferling 2015; NowaK 2015; Brzeska-Zastawna 2018). Concurrently, the source basis has been enriched by materials produced by commercial archaeology, for example at site 8 in Kraków-Bieżanów (KAFLIŃSKA et al. 2015), site 13 in Kokotów (ZASTAWNy 2014) and site 2 in Brzozówka Korzkiewska (NowAK 2017). Rescue excavations in the Puchacza Skała region (Smardzowice site 38) resulted in an abundant series of artefacts as well (ZASTAWNY, NowaK 2012). The research in the Ojców Jura also included excavations in Żarska Cave (WoJENKA et al. 2016). The results of excavations carried out in 1986 at Zofipole have finally been published (DoBRZAŃsKa et al. 2016), 

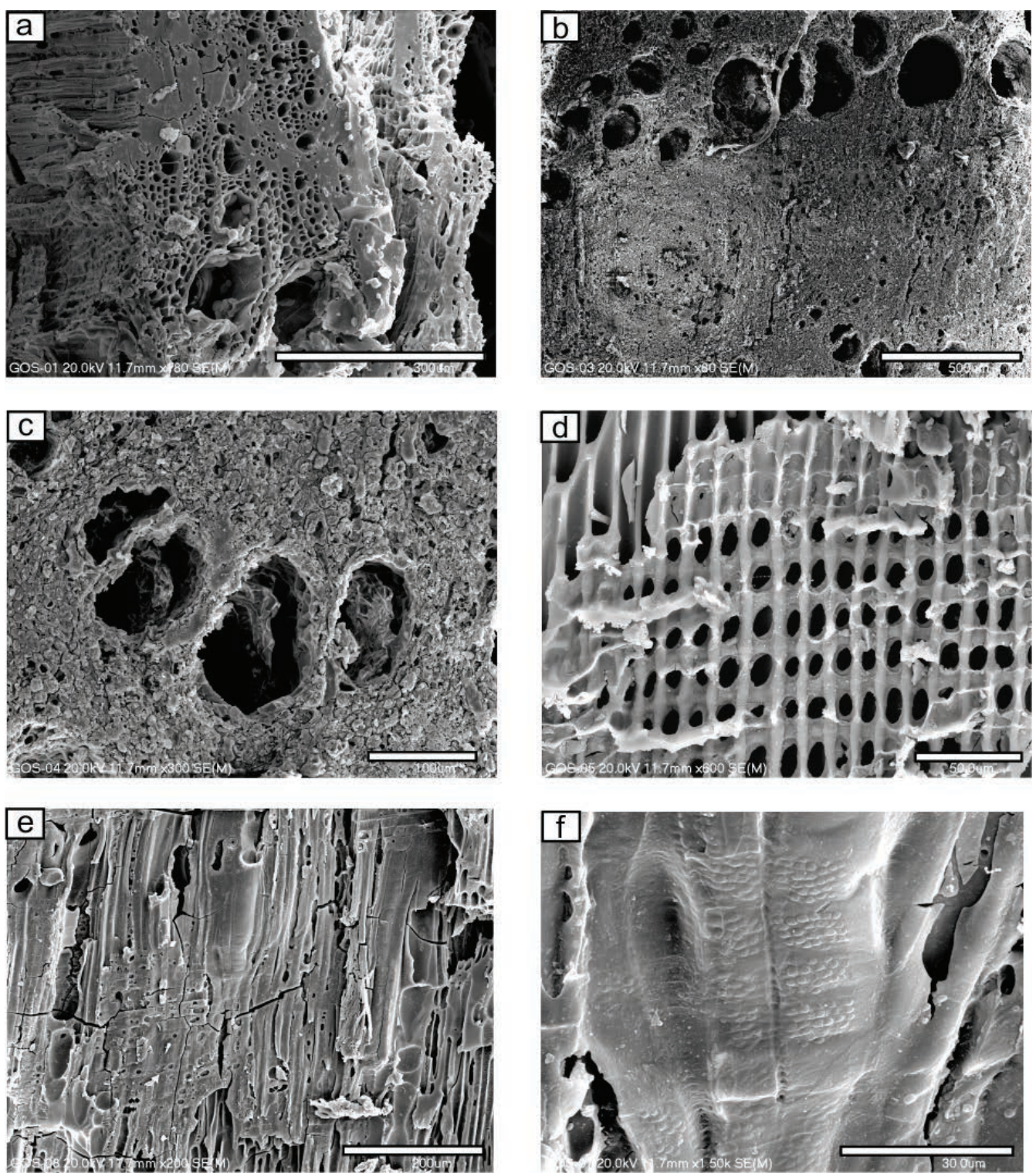

Fig. 21. Goszcza site 1. Charcoal fragments: Quercus sp. in transverse section (a-c), Pinus sylvestris in longitudinal radial section (d), Betula sp. in longitudinal radial section (e-f). Scale bars: $300 \mu \mathrm{m}$ (a), $500 \mu \mathrm{m}$ (b, d), $100 \mu \mathrm{m}$ (c), $200 \mu \mathrm{m}$ (e), $30 \mu \mathrm{m}$ (f). Micrographs by M. Moskal-del Hoyo

and the same applies to the results of excavations at archaeological sites in Nowa Huta (BoBER 1993, 1994, 1995, 1998). Apart from them, it is worth mentioning a burial from site 2 in Zagórze in the gorge of the Skawa River (VALDE-NowAK et al. 2015) and a child burial discovered in the Ciemna Cave in Ojców (VALDE-NowaK et al. 2018).

The character of ceramic artefacts from Goszcza indicates that the analysed assemblage links with the late-classic stage of the Baden culture development in Lesser 
Poland in its youngest horizon, the Epibaden. This is manifested by the presence of stamp-pit ornamentation and by the sharp profiles of vessels decorated in that manner. An analogy for this assemblage can be found in materials of the younger phase at site Nowa Huta-Zesławice I (GodŁowska 1968).

The funerary rite of the Baden culture in Lesser Poland is known from single discoveries of burials. So far, six graves of the Baden culture have been verified as certain (Zastawny 2012, Bober et al. 2012). Among them are two burials from Zesławice. Feature no. 10 was discovered at a depth of $50 \mathrm{~cm}$ as a rectangular pit $(175 \times 85 \mathrm{~cm})$. It contained a skeleton extended on its back with tilted arms bent at the elbows and legs contracted and tilted to the right - most probably under the pressure of the soil. In the lower part of the chest, the bottom part of an amphora was located. The next burial was registered within feature no. 217 - an oval pit $(130 \times 75 \mathrm{~cm})$. At a depth of $30 \mathrm{~cm}$, a skeleton was discovered lying on the left side with the legs sharply contracted and the arms sharply bent at the elbows. In the southern part of the pit, next to the feet, one vessel - an amphora with four handles - was found (ZemetKA 1959). Two other burials are known from site 17 in Kraków-Pleszów. In feature no. 711, a settlement pit, there was a skeleton of a man extended on his back with his arms along his sides. The skeleton was situated along the west-east axis (head towards the west). The burial was furnished with three mugs and a bowl. Feature no. 1326 from the same site - a trapezium-shaped pit - contained a skeleton situated along the NE-SW axis (head towards the SW). It was placed on the right side with legs contracted. The right hand of the deceased rested on the hip, and the left arm was contracted with the hand on the chest. Next to the skeleton, two animal maxillae were found (on the left forearm and by the left knee). Numerous materials of the Baden culture were recognized in the vicinity of the skeleton, but only the mentioned animal maxillae and one bowl are linked with grave goods (ZASTAWNY 2012: 236, 237). The remaining burials are: a burial from site 2 in Zagórze with an unpreserved skeleton dated to the Boleraz phase (containing an amphora reconstructed from small pieces) (VALDE-NowAK et al. 2015) and a child burial from the Ciemna Cave in Ojców linked with the Baden culture (radiocarbon dating) (VALDE-NowAK et al. 2018).

In the studied animal bone assemblage, the remains of cattle, goat/sheep and pig clearly predominate. This spectrum is characteristic for a Neolithic site, where predominantly bones and teeth of cattle prevail (SocHACKi 1981; MAKOwicz-PoliszoT 2002; PIPES et al. 2009), although at some Baden sites pig remains constitute a significant part of animal bone assemblages (GoDŁOwSKA 1968; DoBRZAŃSKA et al. 2016). It is difficult to interpret the high share of goat/sheep remains at Goszcza site, but this result may be affected by the small sample size (only three features excavated). The same explanation can possibly be offered for the unexpected lack of horse remains among wild species. The presence of different body parts of animals and numerous traces of human activity indicate that whole animal carcasses were transported to the settlement and there slaughtered and processed. Surprisingly, numerous traces of dog gnawing observed at remains belong mainly to medium-size animals, and they may reflect a dog-feeding strategy.

The diversified set of osseous artefacts including awls, a chisel, a spatula, and teeth pendants reflects the importance of animals in the everyday life of the inhabitants of the 
settlement. Some of these artefacts were worn or damaged during use, but complete, undamaged specimens are also present.

The state of archaeobotanical research on sites of the culture in question is insufficient to make reliable interpretations of plants used by prehistoric people or to make inferences concerning the past landscape and vegetation types growing in the vicinity. The presence of crops, mainly cereals, in all examined features (Tab. 1) together with the accompanying herbal plants representing segetal and/or ruderal plants may indicate that cultivation took place locally and that cultivated plants played an important role in the diet of the settlement's inhabitants. Among the Baden culture sites in Poland there are only a few with plant assemblages studied, with the majority of plant remains documented in daub fragments. For example, in Szarbia site 9 and Smroków site 17, imprints of cultivated plants belonging to emmer wheat, einkorn wheat and barley together with wild grasses (Poaceae indet.) have been documented (LiTYŃSKA-ZAJĄC 2000, 2010). In Szarbia site 9, in one soil sample taken from an archaeological feature, remains of cultivated (Triticum diccocum and T. monococcum) and wild plants appeared (Bromus sp.) (LityŃsKA-ZAJĄC 2000: 140). Also, plant remains were investigated from sites in which Baden culture materials were mixed with those of the Funnel Beaker culture, like at Bronocice (KruK et al. 2016) and Miechów site 3 (MosKal-Del Hoyo et al. 2017). In addition, several plant assemblages were studied from Funnel Beaker culture sites such as Mozgawa 1-3 (Moskal-Del Hoyo et al. 2018) and Niedźwiedź (Burchard, LITYŃSKA-ZAJĄC 2002), which were partly contemporaneous with the Baden culture. In general, the taxonomic list of plants from settlements dated to the turn of the fourth and third millennia BC is similar to that of other Neolithic sites. The same is true for the dominance of glume wheats, especially emmer wheat, amongst cultivated crops. In the context of the Funnel Beaker culture, sporadic finds of storage pits can be highlighted, such as those from Nowa Huta Mogiła site 62 (GluZA 1983/84; KAPCIA, MuellerBiENIEK 2018), Parchatka (LityŃsKa-ZAJąC 1997), Ćmielów (KLICHOwsKa 1975) and Kraków-Prądnik Czerwony, where grains of emmer are estimated at 150,000 (Rook, NowAK 1993). In all of these storage pits emmer clearly dominated, with T. monococcum in lesser frequency, showing the great importance of emmer in the crop husbandry in the loess areas of Lesser Poland. The late phase at Bronocice, characterized by Baden culture influence, suggests that emmer still was the most important crop, but an increase of Hordeum vulgare was noted and it was sporadically found at other sites, i.e. KrakówMogiła 62 (GLUZA I 1983/84; KRUK et al. 2016). Among other cultivated plants, legumes and oil plants were not usually found at Funnel Beaker culture sites, with the exception of Bronocice and especially Mozgawa, where remains of pulses and flax were quite frequent (MosKaL-DEL Hoyo et al. 2018).

The list of wild plants documented at Goszcza is also analogous to other contemporary sites, especially concerning plants interpreted as weeds and/or ruderal such as Chenopodium album and Galium sp. Also, remains of feather grass Stipa sp. (Fig. 20: f) were found in other sites such as Mozgawa and Miechów site 3 (e.g. MosKAL-DEL Hoyo et al. 2017, 2018), all of them located in loess areas. Due to the lack of grains found, we cannot say whether they were used as food or for other purposes: for example, the feather 
grass awns could have been used for insulating the walls of storage pits, protecting the crop from moisture. They could also have been used as part of clothes ornamentation (BAKels 1992; BienieK, PoKorny 2005). The appearance of awns of Stipa sp. suggests a partially open landscape, since plants of this genus typically grow in xerothermic grasslands, and they can appear in open forests and permanently deforested rocky areas and on steep slopes (CEYnowa-Gietdon 1976; BienieK, PoKorny 2005). The anthracological data are very scarce from the Goszcza site, but the taxonomic list (oak, pine and birch) and the dominance of oak may suggest that open oak-dominated forest grew in the vicinity of the site. Forests of that type have been documented on other sites located in loess regions, in Smroków site 17 (LiTYŃSKa-ZAJąC 2010), Miechów site 3 (Moskal-Del Hoyo et al. 2017) and Niedźwiedź (Burchard, LityŃsKa-ZająC 2002). In Mozgawa, oak and pine were the most important constituents of the anthracological assemblage, but it seems that pine played a more important role than oak in local forests (MosKal-DEL Hoyo et al. 2018). The presence of an open landscape may also indicate increasing impact of people on the local environment.

Based on the materials from Goszcza site 1, we can say little about the basis of plant economy among the Baden culture population. Certainly, crop plants, especially emmer, were typically used. A large amount of chaff in relation to grains may indicate the knowledge of crop cultivation and the local processing of cereals, including removing chaff from grain before food preparation (BOGAARD, JONES 2007). In addition, wild plants may testify that plants were also gathered for various purposes, but their scarcity does not allow for further interpretation. For example, the presence of Lithospermum arvense may be accidental, because only a half of one specimen found and a red dye extracted from its roots can be used for dyeing fabrics (NowIŃsKi 1983, KRUK et al. 2016). One specimen of vetch does not allow for a broader interpretation of this find. The presence of Stipa may be an indication that the population was living in partially open areas. However, Stipa sp. and other plants such as Sambucus nigra, could have been brought to the settlement from more distant places (BAKELS 1992; Mueller-Bieniek, Nalepka 2010; Bieniek, Pokorny 2005). The lack of rich archaeobotanical material does not allow for comprehensive study of plant use among people of the Bade culture, but it is an impetus for wider research on this culture.

ACKNOwLedGements. The authors are grateful to P. Godlewski and Keith Horechka for proofreading. The micrographs were taken with the help of A. Łatkiewicz at the Laboratory of Field Emission Scanning Electron Microscopy and Microanalysis at the Institute of Geological Sciences of the Jagiellonian University, Kraków, Poland. The archaeobotanical analyses were conducted thanks to the Statutory Research Funds of the W. Szafer Institute of Botany.

\section{REFERENCES}

Acsadi G. Y., Nemeskeri J., 1970. History of Human Life. Span and Mortality, Akademia Kiado.

BAKELS C.C., 1992. Fruits and seeds from the Linearbandkeramik settlement at Meindling, Germany, with special reference to Papaver somniferum. Analecta Praehistorica Leidensia 25: 55-68. 
Bieniek A., PoкоRny P., 2005. A new find of macrofossils of feather grass (Stipa) in an Early Bronze Age storage pit at Vlineves, Czech Republic: local implications and possible interpretation in a Central European context. Vegetation History and Archaeobotany 14: 295-302.

Binford L. R., 1981. Bones: ancient men and modern myths. Academic Press, New York.

Bober J., 1993. Osada kultury ceramiki promienistej w Krakowie - Nowej Hucie - Mogile w rejonie Kopca Wandy. Część I -Materiały. Materiały Archeologiczne Nowej Huty 16: 7-53.

Bober J., 1994. Osada kultury ceramiki promienistej w Krakowie - Nowej Hucie - Mogile w rejonie Kopca Wandy. Część II - Analiza. Materiały Archeologiczne Nowej Huty 17: 13-40.

Bober J., 1995. Materiały kultury ceramiki promienistej z Krakowa - Nowej Huty - Cła. Materiały Archeologiczne Nowej Huty 18: 11-16.

Bober J., 1998. Najnowsze materiały kultury ceramiki promienistej ze stanowiska 5, 5A, 5B w KrakowieNowej Hucie (Wyciąże). Materiały Archeologiczne Nowej Huty 21: 7-26.

Bober J., 2015. Pottery of the Baden Vulture in Lesser Poland on the basis of findings in the KrakówNowa Huta. In: Nowak M., Zastawny A. (eds.), The Baden culture around the Western Carpathians. Via Archaeologica, Kraków: 221-259.

Bober J., Valde-Nowak P., Zastawny A., 2012. Kultura badeńska - katalog źródeł. In: Czekaj-Zastawny A. (ed.), Obrządek pogrzebowy kultur pochodzenia naddunajskiego w neolicie Polski południowo-wschodniej (Funerary Rite of Danubian Cultures in the Neolithic of southeastern Poland). Kraków: 453-469.

BogaARD A., Jones G., 2007. Neolithic farming in Britain and central Europe: contrast or continuity? In: Whittle W A., Cummings V. (eds.) Going over: the Mesolithic - Neolithic transition in north - west Europe. British Academy. London.

BrZeska-Zastawna A., 2018. The current state of research on the flint industry in the Pre-Baden and Classic Baden horizons in western Lesser Poland. In: Valde-Nowak P., Sobczyk K., Nowak M., Źrałka J. (Eds) Multas Per Gentes Et Multa Per Saecula. Amici Magistro Et Collegae Suo Ioanni Christopho Kozłowski Dedicant. Kraków: 511-520.

Buikstra J., Ubelaker D. H., 1994. Standards for data collection from human skeletal remains. Arcansans, Archeological Survey Research: 44.

Burchard B., LityŃSKa-ZaJąc M., 2002. Plant remains from the Funnel Beaker Culture site at Niedźwiedź, Słomniki commune, Małopolska province. Acta Palaeobotanica 42 (2): 171-176.

Ceynowa-Giędon M., 1976. Ostnice sekcji „Pennatae” w Polsce. Rozprawy Uniwersytetu M. Kopernika, Toruń.

Chabal L., 1997. Forêts et sociétés en Languedos (Néolithic final, Antiquité tardive). L'athracologie, méthode et paléoécologie. Documents d'Archéologie Française. 63. Éditions de la Maison des sciences de l'homme, Paris.

Cuhna E., Baccino E., Martille L., Ramsthaler F., Priet J., Schuliar Y., Lynnerup N., Cattaneo C., 2009. The problem of aging human remains and living individuals: A review. Forensic Science International 193: 1-13.

Czarnowicz M., Ochal-Czarnowicz A., 2011. Sprawozdanie z badań archeologcznych przeprowadzonych w Goszczy na stan. 1 (w archiwum Małopolskiego Konserwatora Zabytków w Krakowie).

DobrZAŃSKa H., WilCZyŃSKi J., ZaSTAWNy A., 2016. The settlement of the Baden culture at site 1 in Zofipole, Kraków district (results of excavations conducted in 1986). Sprawozdania Archeologiczne 68: 223-262.

Fosse P., Wajrak A., Fourvel J.B., Madelaine S., Esteban-Nadal M., Cáceres I., Yravedra J., Prucca A., Haynes G., 2012. Bone Modification by Modern Wolf (Canis lupus): A Taphonomic Study From their Natural Feeding Places. Journal of Taphonomy 10(3-4): 197-217. 
GinTer B., KozŁowski J. K., 1990. Technika obróbki i typologia wyrobów kamiennych paleolitu, mezolitu i neolitu. Warszawa.

GLuZA I. 1983/1984. Neolithic cereals and weeds from the locality of the Lengyel culture at Nowa Huta - Mogiła near Cracow. Acta Paleobotanica 23: 123-184.

GodŁowska M., 1968. Materiały z osady kultury ceramiki promienistej w Zesławicach Dłubni (KrakówNowa Huta) na stanowisku I. Materiały Archeologiczne Nowej Huty 1: 91-172.

GodŁowska M., 1979. Plemiona kultury ceramiki promienistej. In: Hensel W., Wiślański T. (eds.), Prahistoria Ziem Polskich II: 302-317.

HAYNES G., 1983. A guide for differentiating mammalian carnivore taxa responsible for gnaw damage to herbivore limb bones. Paleobiology 9(2): 164-172.

Hillson S., 2005. Teeth. Oxford. 388 pp.

Kaczanowska M., 1982/1983. Przemysł Kamienny kultury ceramiki promienistej. Acta Archaeologica Carpathica 22: 62-95

Kaczanowska M., KozŁowski J. K., 1976. Studia nad surowcami krzemiennymi południowej części Wyżyny Krakowsko-Częstochowskiej. Acta Archaeologica Carpathica 16: 201-216.

Kaflinska M., Wójcik I. Stefański D., 2015. New settlement of the Baden culture at site 8 in KrakówBieżanów. In: Nowak M., Zastawny A. (eds.), The Baden culture around the Western Carpathians. Via Archaeologica, Kraków: 313-336.

KaPCia M., Mueller-BienieK A., 2018. Archaeological analysis of abundant cereal finds from Kraków Nowa Huta Mogiła 62 - getting back to the old story. Folia Quaternaria 86: 217-231.

Klein R. G., Cruz-Uribe K., 1984. The Analysis of Animal Bones from Archaeological Sites, Univ. of Chicago Press, Chicago.

KLICHOwsKa M., 1975. Najstarsze zboża z wykopalisk polskich [The oldest cereals of the Polish archaeological sites]. Archeologia Polski 20 (1): 83-143.

Kondracki J., 2002. Geografa regionalna Polski. Warszawa.

Kozıowski J. K., 1968. Materiały neolityczne i eneolityczne odkryte na stanowisku Nowa Huta - Wyciąże (badania w latach 1950-1952). Materiały Archeologiczne Nowej Huty 1: 13-90.

KRUK J., 1987. Karta Ewidencyjna Stanowiska Archeologicznego Goszcza 1 (w archiwum Małopolskiego Konserwatora Zabytków w Krakowie).

Kruk J., LityŃSka-ZająC M., Milisauskas S., 2016. Gospodarka roślinna w neolicie. Studium przypadku / Neolithic plant cultivation at Bronocice. Institute of Archaeology and Ethnology, Polish Academy of Sciences. Kraków.

KulPa WŁ., 1974. Nasionoznastwo chwastów. Wydanie II uzupełnione. Państwowe Wydawnictwo Rolnicze i Leśne. Warszawa.

Lasota-Moskalewska A., 2007. Podstawy archeozoologii, Szczątki ssaków. Warszawa.

LiTYŃSKA-ZAJĄC M., 1995. Charakterystyka niektórych aspektów upraw na podstawie analizy szczątków roślinnych ze stanowiska $12 \mathrm{w}$ Parchatce gm. Kazimierz Dolny, woj. Lubelskie. Sprawozdania Archeologiczne 47: 255-263.

LiTYŃSKA-ZAJąC M., 1997. Roślinność i gospodarka rolna w okresie rzymskim. Instytut Archeologii i Etnologii PAN, Kraków.

LiTYŃSKA-ZAJĄC M., 2000.Wyniki analizy materiałów roślinnych z obiektu kultury badeńskiej ze stanowiska 9 w Szarbi Zwierzynieckiej, gm. Skalbmierz. Sprawozdania Archeologiczne 52: 139-142.

LiTYŃSKA-ZAJĄC M., 2005. Chwasty w uprawach roślinnych w pradziejach i wczesnym średniowieczu. Instytut Archeologii i Etnologii Polskiej Akademii Nauk, Kraków. 
LiTYŃSKA-ZAJĄC M., 2010. Botanical analysis of the multicultural site in Smroków, Słomniki commune. Sprawozdania Archeologiczne 62: 335-352.

LityŃSKa-Zając M., Wasylikowa K., 2005. Przewodnik do badań archeobotanicznych. Sorus, Poznań.

LUTNICKI W., 1972. Uzębienie zwierząt domowych. Warszawa-Kraków.

Lyman R. L., 1994. Vertebrae Taphonomy. Cambridge University Press, Cambridge.

Makowicz-Poliszot D., 2002. Zwierzęce szczątki kostne ze stanowiska kultury pucharów lejkowatych z Zawarży. In: Kulczycka-Leciejewiczowa A. (ed.) Zawarża, osiedle neolityczne w poludniowopolskiej strefie lessowej. Wrocław: Instytut Archeologii i Etnologii Polskiej Akademii Nauk: 135-160.

Marguerie D., Hunot J.-Y. 2007. Charcoal analysis and dendrology: data from archaeological sites in north-western France. Journal of Archaeological Science 34(9): 1417-1433.

Moskal-Del Hoyo M., Mueller-bieniek A., Alexandrowicz W. P., Wilczyński J., WęDzicha S., KapCiA M., PrzybyŁa M., 2017. The continuous persistence of open oak forests in the Miechów Upland (Poland) in the second half of the Holocene. Quaternary International 458: 14-27.

Moskal-Del Hoyo M., Wachowiak M., Blanchette R. A., 2010. Preservation of fungi in charcoal. Journal of Archaeological Science 37 (9): 2106-2116.

Moskal-Del Hoyo M., Wacnik A., Alexandrowicz W. P., Stachowicz-Rybka R., Wilczyński J., Węidzicha S., Szwarczewski P., Korczyńska M., Cappenberg K., NowaK M., 2018. Open country species persisted in loess regions during the Atlantic and early Subboreal phases: new multidisciplinary data from southern Poland. Review of Palaeobotany and Palynology 253: 49-69.

Mueller-BienieK A., NALEPKA D., 2010. Czy znaleziska ostnicy (Stipa sp.) z neolitu południowych Kujaw świadczą o istnieniu muraw kserotermicznych w optimum klimatycznym? [Do findings of feather grass (Stipa sp.) from the Neolithic of Southern Kujawy area indicate the existence of xerothermic grasslands during the climatic optimum?] In: H. Ratyńska, B. Waldon (eds.). Ciepłolubne murawy w Polsce - stan zachowania i perspektywy ochrony. Wyd. Uniwersytetu Kazimierza Wielkiego, Bydgoszcz: 235-248

Mueller-BienieK, A.,Pyzel J., Kapcia M., 2018. Chenopodium Seeds in Open-Air Archaeological Sites - How to Not Throw the Baby Out with the Bathwater. Enviromental Archaeology 2018: 1-13.

NowAK M., 2015. Workshop of the tatrahedral flint axes discovered during rescue excavations at site 13 in Zakrzów, Wieliczka district, Lesser Poland. In: Nowak M., Zastawny A. (eds.), The Baden culture around the Western Carpathians. Via Archaeologica, Kraków: 361-370.

NowAK M., 2017. Obiekt kultury badeńskiej na stanowisku Brzozówka Korzkiewska 2 (AZ P 100-56/43), gm. Zielonki, Prądnik. Prace i Materiały Muzeum im. W. Szafera 27: 181-188.

NowiŃski M., 1983. Dzieje upraw i roślin leczniczych. Państwowe Wydawnictwo Rolnicze i Leśne. Warszawa.

Pelisiak A., 2006. The exploitation and distribution of flints from the central part of Polish Jura in the Late Neolithic. Analecta Archaeologica Ressoviensia 1: 73-86.

PioneK J., 1999. Biologia populacji pradziejowych. UAM, Poznań.

Pipes M.-L., Kruk J., Makowicz-Poliszot D., Milisauskas S., 2009. Funnel Beaker Animal Husbandry at Bronocice. Archaeologia Baltica 12: 31-45.

Reitz E. J., Wing E. S., 1999. Zooarchaeology. Cambridge.

Rook E., 1971. Materiały kultury ceramiki promienistej odkryte na stanowisku w Nowej Hucie - Pleszów (badania 1954-1963). Materiały Archeologiczne Nowej Huty IV: 11-237.

Rook E., NowaK M., 1993. Sprawozdanie z badań wielokulturowego stanowiska w Krakowie-Prądniku Czerwonym w latach 1990 i 1991 (A report on the research on a multi-cultural site in Kraków-Prądnik Czerwony, in years 1990-1991). Sprawozdania Archeologiczne 45: 35-71. 
RutKowski L., 1998. Klucz do oznaczania roślin naczyniowych Polski Niżowej. Wydawnictwo Naukowe PWN. Warszawa.

Scheuer L., Black S., 2004. Developmental juvenile osteology. Elsevier - Academic Press, Londyn.

Schmid E., 1972. Atlas of animal bones: for prehistorians, archaeologists and Quaternary geologists. Amsterdam-London-New York.

SchweIngruber F.H., 1990. Anatomie Europäischer Hölzer. Paul Haupt Berne und Stuttgart Publishers, Bern-Stuttgart.

Shipman P., Foster G., Schoeninger M., 1984. Burnt bones and teeth: an experimental study of color, morphology, crystal structure and shrinkage. Journal of Archaeological Science 11: 307-325.

Sochacki Z., 1981. Z zagadnień ekonomiczno-społecznych kultury ceramiki promienistej w Europie. Archeologia Polski 26(1): 41-70.

Sоснаскі Z., 1988. Zespół osadniczy kultury ceramiki promienistej w Krakowie-Zesławicach. Warszawa.

Trela-Kieferling E., 2015. Workshop of Jurassic G flint core tools at site 7 in Przybysławice, Lesser Poland. In: Nowak M., Zastawny A. (eds.), The Baden culture around the Western Carpathians. Via Archaeologica, Kraków: 353-360.

Valde-Nowak P., Stefański D., Szczepanek A., 2018. A Neolithic Child Burial from Ciemna Cave in Ojców National Park, Poland. In: Werra D. H.\& Woźny M. (eds.), Between History and Archaeology. Papers in honour of Jacek Lech: 279-288.

Valde-Nowak P., Gil-Drozd A., Kraszewska A., Paternoga M., 2015. The proto-Boleraz grave in the Western Beskidy Mts., Lesser Poland. In: Nowak M., Zastawny A. (eds.), The Baden culture around the Western Carpathians. Via Archaeologica, Kraków: 371-380.

Wojenka M., WilczyŃski J., Zastawny A., 2016. Archaeological excavations in Żarska Cave in Żary, Kraków district, 2012-2015: an interim report. Recherches Archéologique Nouvelle Serie 8: 185-204.

Zastawny A., 1999. Uwagi na temat chronologii osadnictwa kultury badeńskiej w zachodniej części Małopolski. Sprawozdania Archeologiczne 51: 9-55.

ZaStaWny A., 2000. Kultura badeńska w regionie wielicko-bocheńskim - stan i problematyka badań. Sprawozdania Archeologiczne 52: 9-42.

Zastawny A., 2006. Osadnictwo społeczności badeńskeigo kręgu kulturowego w Jurze Ojcowskiej na tle regionów sąsiednich. In: Lech J., Partyka J (eds.), Jura Ojcowska w pradziejach i początkach państwa polskiego. Ojców: 439-458.

Zastawny A., 2012. Groby kultury badeskiej w Małopolsce (The graves of the Baden Culture in lesser Poland). Studia Archaeologica Brunensia M 17: 233-254.

ZASTAWNY A., 2014. Neolityczne osadnictwo strefy „piaskowej” południowego obrzeżenia doliny Wisły pod Krakowem w świetle badań na stanowisku 13 w Kokotowie, gm. Wieliczka, woj. Małopolskie, Raport 9: 11-52.

Zastawny A., 2015a. The Baden complex in Lesser Poland - horizons of cultural influences. In: Nowak M., Zastawny A. (eds.), The Baden culture around the Western Carpathians. Via Archaeologica, Kraków: $119-150$.

Zastawny A., 2015b. Absolute chronology of the Baden culture in Lesser Poland - new radiocarbon dates. In: Nowak M., Zastawny A. (eds.), The Baden culture around the Western Carpathians. Via Archaeologica, Kraków: 191-219.

Zastawny A., Nowak M., 2012. Badania wykopaliskowe w rejonie Puchaczej Skały w dolinie Prądnika (Smardzowice st.38), Prądnik. Prace i Materiały Muzeum im. W. Szafera 27: 55-72.

ZemeŁKa, S. 1959. Groby kultury ceramiki promienistej i sznurowej w Zesławicach, pow. Kraków (Nowa Huta). Materiały Archeologiczne vol. I: 81-90. 